\title{
THE DETERMINATE SENTENCING MOVEMENT AND THE EIGHTH AMENDMENT: EXCESSIVE PUNISHMENT BEFORE AND AFTER RUMMEL v. ESTELLE
}

\author{
MARTIN R. GARDNER*
}

Indeterminate sentencing, ${ }^{1}$ once an indomitable element of American penology, has recently come under attack by theorists and politicians of every ideological persuasion. ${ }^{2}$ Several writers have criticized the injustice of indeterminate sentencing both im its failure to punish similarly situated offenders equally ${ }^{3}$ and in its disregard for the princi-

* Professor of Law, University of Nebraska. B.S. 1969, J.D. 1972, University of Utah. The author wishes to thank Candy Marshall, a 1980 graduate of the University of Nebraska College of Law, for her substantial assistance in the preparation of this Article.

THE FOLLOWING CITATIONS WILL BE USED IN THIS ARTICLE:

Twentieth Century Fund Task force on Criminal Sentencing, Fair and Certain PUnishment (1976), hereinafter cited as TASK ForCe REPORT;

A. voN HirSCH, Doing Justice (1976) hereinafter cited as A. von HirSCH;

A. von Hirsch \& K. Hanrahan, The Question of Parole: Retention, Reform or Abolition? (1979), hereinafter cited as A. von HirSCh \& K. HANRAHAN.

1. The expression "indeterminate sentencing" has several meanings. It nay describe a process in which the judge or other sentencing authority is vested with wide discretion in setting either minimuın and maximuin terms of mcarceration (e.g., 10 to 20 years) or an exact term of incarceration (e.g., 10 years or 20 years). These terms may later be administratively modified. See Giorno, Sentencing in Criminal Cases: How Great the Need for Reform?, 13 U. RicH. L. REv. 899, 901 (1979). The expression can also refer to a system in which an administrative board sets the duration of a sentence while the sentence is being served. Finally, "indeterminate sentencing" can describe a process whereby a noininally fixed sentence is subject to the normal rules of parole. A correctional agency administers these rules after a statutorily prescribed percentage of the sentence has been served. Dershowitz, Indeterminate Confinement: Letting the Therapy Fit the Harm, 123 U. PA. L. Rev. 297, 299 (1974).

In short, the term "describe[s] any prison sentence for which the precise term of confinement is not known on the day of judgment but will be subject within a substantial range to the later decision of a parole board or some comparable agency under whatever name." M. FrANKEL, Criminal Sentences 86 (1972).

2. Disillusionment with indeterminate sentencing is expressed by a range of thinkers from Alan Dershowitz to Ernest van den Haag and by a range of pohiticians from Senator Edward M. Kennedy to James Baker, a former Republican nominee for Texas Attorney General. See TASK Force Report 3-4; E. van den HaAg, Punishing Criminals 176-77, $191-95$ (1975); Crump, Determinate Sentencing: The Promises and Perils of Sentence Guidelines, 68 KY. L.J. 1, 4 n.6 (1979); Kennedy, Symposium on Sentencing (pt. 1), 7 Hofstra L. Rev. 1, 1-4 (1978).

3. See, e.g., A. voN Hirsch 72-74. 
ple of proportioning punishment to the gravity of the offense. ${ }^{4}$ Others fault indeterminate sentencing for its ineffectiveness in deterring future criminal activity. ${ }^{5}$ Calls for determinate sentencing systems, ${ }^{6}$ already heeded by several legislatures, ${ }^{7}$ abound and almost certainly will increase. ${ }^{8}$

Although determinate sentencing systems are often advocated to promote justice, they carry substantial risks of undue harslmess be-

4. See, e.g., American Friends Serv. Comm., Struggle for Justice 30-31 (1971). See also M. FRANKeL, supra note 1, at 8-10.

5. See generally N. MORRIS, THE FUTURE OF lMPRISONMENT (1974); J. WILSON, THINKING About CRIme 162-82 (1975); van den Haag, Punitive Sentences, 7 Hofstra L. Rev. 123 (1978).

6. A determinate sentencing system is one in which discretion in fixing the term of incarceration is withdrawn from the judge or other sentencing authority and replaced by a legislatively determined term, either fixed or narrowly variable, for each defined crime. See text accompanying notes 43-47 infra.

7. As of October 1980, no jurisdiction has adopted a complete system of determinate sentencing. Many state systems do, however, contain elements of fixed sentencing, manifested particularly in "habitual offender" statutes. See Cruinp, supra note 2, at 7 n.19. For other examples of fixed sentencing statutes see FLA. STAT. ANN. § 775.087(2) (West Supp. 1980) (mandating a miniInum three-year sentence for possession of a firearm during the commission of certain violent crimes); Мich. Comp. Laws ANN. § 750.227(b) (Supp. 1976-77), as amended by Act of Feb. 11, 1976, Pub. Act No. 6 (effective Jan. 1, 1977) (mandating a two-year prison sentence for anyone who possesses a firearm at the time of the commission of a felony); OKLA. STAT. ANN. tit. 63, § 2401 (West Supp. 1978) (inandating fixed sentences for certain violations of the Uniform Controlled Substance Act, OKLA. STAT. ANN. tit. 63, §§ 2-101 to -610 (West Supp. 1978)); WASH. Rev. CODE ANN. $§ 9.92 .090$ (West 1977) (mandating life imprisonment for the commission of a third felony); W. VA. CODE § 61-11-18 (Michie 1977) (mandating hife imprisonment upon conviction of a third felony).

A number of states have recently enacted presumptive sentencing systeins. See, e.g., Cal. Penal Code $\S \S 1170-1170.6$ (West Supp. 1980); Ill. ANN. Stat. ch. 38 \$ 1005-8-1 (Sinith-Hurd Supp. 1980); IND. Code ANN. \$§ 35-50-1-1 to 35-50-6-6 (Burns Supp. 1979); Minn. STat. ANN. $\S \S 244.01$-.11 (West Supp. 1979); 18 PA. Cons. SraT. ANN. $\$ \S 1381-1386$ (Purdon Supp. 1980). In addition, 35 other states are considering revisions of their sentencing laws. See Zalman, Making Sentencing Guidelines Work: A Response to Professor Coffee, 67 GEO. L.J. 1005 (1979). See generally Mandatory Sentencing Statutes Enacted in Eighteen States, JUSTICE AssistanCE NEws, April 1980 , at 9.

8. See authorities cited in notes 2-5 supra. See generally D. FOGEL, WE ARE THE Living Proof: The Justice Model For Corrections (1975). Perhaps the purest systein of inandatory sentencing is that advocated in AMERICAN FRIENDS SERv. CoMm., supra note 4, at 144: "IA]ll offenders in a broad class-such as type of crime, but not according to the unique characteristics of the individual-are to be treated alike. Whatever sanction . . . is imposed is to be fixed by law. There is to be no discretion in setting sentences . . . . A representative proposal of a presumptive sentencing system is set forth in A. vON HIRSCH 99-101.

One commentator has described the current plea to replace indeterminate with deterninate systems as an "au courant cause [that] may become a 'motherhood' issue that all cspouse in principle and defend vociferously against already vanquished opponents." Coffee, The Repressed Issues of Sentencing: Accountability, Predictability, and Equality in the Era of the Sentencing Commission, 66 GEO. L.J. 975, 976 (1978). Another commentator notes: "Determinate sentencing has arrived im this nation with the force of an idea whose time has conne. From Maine . . to California . . . inore and inore jurisdictions are considering, drafting and adopting definite sentencing systems." Crump, supra note 2, at 3. 
cause of their inflexibility. 9 Soine proposed determinate systems, as well as some laws already in use, ${ }^{10}$ ignore circumstances that do not rise to the level of substantive defenses but that nevertheless relate to the individual offender's culpability. ${ }^{11}$ This failure to link pumshment to the character and circumstances of the offender as well as to his offense, leads to undeservedly harsh sentences. ${ }^{12}$

Recent proposals for determinate sentencing typically attempt to proportion the degree of punishment to the seriousness of the offense, thus assuming the feasibility of an a priori measurement of offender fault and victim harm in determining appropriate sentences. ${ }^{13}$ Because such ineasurements are at best inexact, ${ }^{14}$ the determinate sentencing

9. See text accompanying notes $45-47$ infra.

10. For an example of a proposed system of essentially fixed sentencing see generally AMER1CAN FRIEndS SERv. Comm., supra note 4. For examples of individual statutes fixing punishment to offense, see note 7 supra.

11. Fixed-punishment statutes generally dictate a specific penalty upon conviction of the offense, see note 7 supra, established by proving the actus reus and mens rea aspects of the crime. Although traditional criminal responsibility defenses such as insanity and mistake of fact are available to offenders in fixed-sentencing systems, the traditional substantive defenses do not permit a thorough inquiry imto offender culpability. Criteria such as the offender's motives (as opposed to his intentions) for committing the crime, his umique powers of self-control, the strength of his temptations, his exposure to debilitating social and economic deprivation-indeed his whole character-are all relevant to assessing culpability. See A. EwING, THE MORALITY of PUNISHment 37 (1929); Ezorsky, The Ethics of Punishment, in Philosophical Perspectives on PunlshMENT xxii-xxvi (G. Ezorsky ed. 1972). But such an inquiry is precluded at the guilt stage of the criminal trial; it is relevant only at sentencing and then only under indeterminate sentencing models. See J. Hall, General Principles of Criminal Law 96-101 (2d ed. 1960); S. Rubin, Law of Criminal Correction 82-83 (2d ed. 1973).

12. See, e.g., In re Foss, 10 Cal. 3d 910, 519 P.2d 1073, 112 Cal. Rptr. 649 (1974) (holding a mandatory minimuin term of ten years for a second narcotics offense too harsh for the offender in his circumstances).

13. See, e.g., A. vON HiRSCH 66-94. "Seriousness" is a function of the characteristic harmfulness of the conduct and the culpability of the offender. A "proportionate" sentence is one that matches in severity the degree of culpability of the offender plus the harm (or risk of harm) to others in the offense itself. $I d$.

14. Some of the problems inherent in the endeavor to proportion punishments to the gravity of offenses are noted by Hugo Adam Bedau in his discussion of von Hirscli's suggestions, see note 13 supra.

First, the principle of commensurate deserts requires a mode of measurentent for degrees of culpability in offenders. Even if we can agree that a malicious killer is morally and legally more culpable than an accidental killer, how are we to answer the question, 'How inuch more culpable is he-twice as culpable? ten tines? seven and one half times?' Second, the principle needs a node of measurement for degrees of larm inflicted by different offenses. Granted that murder is more harmful than rape, how much worse is it in terns of harn to the victim (or to society)? Twice as harmful? Ten times as harmful? The concepts of culpability and harmfulness are not like the concepts of temperature or ductility because we lack standard units im terms of which to measure then, solnething we do not lack for the latter. Third, we need a way of combining the two concepts-culpability and harmfulness-into one cominon concept of gravity of offense. Without a cominon ineasure for these concepts, there is no way of telling, e.g., whether an offense that falls on the mid-point of the culpability scale and the bottom of the harmfulness scale is exactly as grave or lhalf as grave, or twice as grave, as an offense that 
movement will likely precipitate disagreements about the "proper" punishment for a given crime. ${ }^{15}$ The disagreements are certam to be refiected in cross-jurisdictional disparities im punishment for particular offenses. Such disparities im turn will likely fuel claims of poor legislative determinations of punishment from offenders who receive harsher sentences for offenses than they would have received for the sanie crime elsewhere. ${ }^{16}$

Although these problenis also exist in systenis of mdeterminate sentencing, ${ }^{17}$ these systeins' typically wide range of legislative penalties for a given offense as well as their broad grants of judicial and administrative discretion, provide sone cushion agamst injustice. Under indetermmate schemes, the sentencing authority can consider a wide variety of circumstances bearing on the offender's fault in fashioning sentences within the broad range of legislatively set penalties for the particular crime. ${ }^{18}$ This flexibility promotes dispositions consistent with the deserts of individual offenders. Indeterminate sentencing systeins also lessen the possibility of punishment disproportionate to a given offense by allowing the judge to use probation in lieu of imprisonment, or to impose the minimum sentence legislatively established for the offense, or by permitting correctional authorities to grant early parole release. ${ }^{19}$

\footnotetext{
falls on the mid-point of the harmfulness scale but at the bottom of the culpability scale. Culpability and harmfulness seem to be not even as like each other as the proverbial apples and oranges; the latter are, after all members of a common genus, whereas no genus subsumes both degrees of fault and degrees of harm.

Bedau, Concessions to Rctribution in Punishment, in Justice and Punishment 51, 64 (J. Cederblom \& W. Blizek eds. 1977). See also Pincoffs, Are Questions of Desert Decidable?, in Justice AND PUNishment, supra, at $75,85$.

15. Soine commentators think that the recent attempt at determinate sentencing by the Indiana Legislature, for example, see note 7 supra, establishes excessive penalties. See A. voN Hirsch $\& \mathrm{~K}$. HANRAHAN 86. For an illustration of the divergence of scholarly opinion about which penalties are proportionate to given crimes, compare the kinds and degrees of penalties recommended in A. voN HiRSCH 106-17 (relatively short periods of incarceration, capital punishment impermissible), with those spelled out in D. FoGEL, supra note 8, at 254-55 (longer periods of incarceration, capital punishment permitted). See also Alschuler, Sentencing Reform and Prosecutorial Power: $A$ Critique of Recent Proposals for 'Fixed' and 'Presumptive' Sentencing, 126 U. PA. L. REv. 550, 569 (1978); Wilson, The Political Feasibility of Punishment, im JustiCe AND PUnishment, supra note 14 , at $107,108-10$.

16. Cases in which offenders have inade such eighth amendment arguments under existimg determinate sentencing legislation include Hart v. Coimer, 483 F.2d 136, 141-42 (4th Cir. 1973), cert. denied, 415 U.S. 983 (1974); In re Foss, 10 Cal. 3d 910, 917-18, 519 P.2d 1073, 1077, 112 Cal. Rptr. 649, 653 (1974).

17. A vivid exaunple is In re Lynch, 8 Cal. 3d 410, 503 P.2d 921, 105 Cal. Rptr. 217 (1972) in which the California Supreine Court found an indeterminate sentence possibly amounting to hife imprisonment to be unduly harsh as applied to an offender convicted of a second offense of indecent exposure.

18. See note 11 supra.

19. For a discussion of indeterminate sentencing and its use of parole see A. vON HIRSCH \& K. Hanrahan 27-38.
} 
Nevertheless, the question of disproportionate penalties under emerging determinate sentencing systems did not, until recently, pose a significant problem. Nascent doctrine under the cruel-and-unusualpunishments clause of the eighth amendment ${ }^{20}$ and analogous state constitutional provisions offered promise as a judicial means well suited to solving the problem of the disproportionality of punishment in an era of determinate sentencing. ${ }^{21}$ The recent Supreme Court decision in Rummel v. Estelle, ${ }^{22}$ however, makes it doubtful that defendants can contmue to use the eighth amendment in such fashion im non-capital cases.

This Article (1) reviews the trend toward determinate sentencing and the problems that have arisen and that may arise; (2) shows that before Rummel a developing body of case law was satisfactorily solving those problems; (3) analyzes Rummel and its departure from the preceding case law; and (4) evaluates the likely alternatives to judicial review for preventing excessive punishment.

\section{The Determinate Sentencing Trend and the Problems of EXCESSIVE PunISHMENT}

Although the shift towards determinate sentencing has been discussed in great detail, ${ }^{23}$ an overview of that shift is necessary to illustrate the issues that are likely to pose probleins. Because determinate sentencing inay take a variety of forms, it is also necessary to examine these varieties closely and to discuss the specific problems of excessive punishment entailed in each.

\section{A. The Decline of Indeterminate Sentencing.}

Until recently indeterminate sentencing was a component of alinost all American penal systems. ${ }^{24}$ Although many systeins contained some elements of determinacy-mandatory penalties for habitual offenders, for exanple ${ }^{25}$ - the exercise of broad judicial and administrative discretion in tailoring sentences for particular offenders characterized the sentencing practice. Sentencing was designed to re-

20. "[C]ruel and unusual punishments [shall not be] inflicted." U.S. CoNST. amend VIII.

21. See notes 63-155 infra and accompanying text.

22. 445 U.S. 263 (1980). See notes 159-206 infra and accompanying text for a discussion of Rummel.

23. See, e.g., R. Singer, Just Deserts 1-34 (1979); Crump, supra note 2.

24. "[T]he administrative sentencing inodel with its indeterminate sentence is the dominant mechanism of involuntary confinement currently employed in the United States." Dershowitz, Background Paper, in TASK FORCE REPORT 67, 97 (1976). "At least forty states and the federal government utilize what is known as indeterminate sentencing." Giorno, supra note 1 , at 900.

25. See Crump, supra note 2, at 6-7. 
habilitate, not to punish or deter criminal offenders. ${ }^{26}$ The length of prison sentences was therefore determined less by the seriousness of the crime than by the individual offender's need for treatment and his propensity for future criminal behavior. The emphasis on rehabilitation precluded a priori legislative sentencing determinations and imstead required grants of considerable discretion to sentencing authorities. ${ }^{27}$ Not only were deterrence and retribution only famtly reflected in imdeterminate sentencing systeins, but advocates of such systems often characterized those considerations as remnants of outmoded penology, inappropriate for an enlightened sentencing theory. ${ }^{28}$

All of this has changed. In the face of a steadily rising crime rate, penologists and legislators have now begun to question whether imdeterminate sentencing actually achieves its objectives. ${ }^{29}$ Recent studies have cast doubt on the ability of the criminal justice system to rehabilitate offenders; the data indicate that treatment programs have seldom reduced, and in soine cases have actually increased, recidivism, rates. ${ }^{30}$ Similarly, there is widespread disillusiomnent with indetermmate sentencing as a means of preventive detention of dangerous persons. Accurately predicting dangerousness is extremely difficult. ${ }^{31}$ Judges and

26. Carlson, The Future of Prisons, TRlal, March 1976, at 29; Dershowitz, supra note 1, at 298-99; Giorno, supra note 1, at 900-01.

27. Indeterminate sentencing vests broad discretionary power in prison and parole authorities along with various diagnostic and treatınent specialists, on the assumption that these people are best qualified to make decisions as to each inmate's need for treatunent. Dershowitz, supra note 24 , at $93-98$.

28. "The salient 20th century fact about criminal law is widespread skepticism of punishment. . . . [R]etribution is sharply disparaged as, at best, a disguised form of vengeance." Hall, Justice in the 20th Century, 59 CAL. L. REV. 752, 753 (1971). "[T]he concept of punishment has no place in enlightened crimimology." Lelyveld, in PuNISHMENT: FoR AND AGAINST 57, 81 (H. Hart ed. 1971). The 1966 Manual of Correctional Standards publisled by the Annerican Correctional Association stated the "inodern" view in unequivocal terms:

Punishment as retribution belongs to a penal philosoplty that is arcliaic and discredited by listory .... Penologists in the United States today are generally agreed that the prison serves most effectively for the protection of society against crime when its inajor emphasis is on relrabilitation. They accept this as a fact that no longer needs to be debated.

Quoted in Carlson, supra note 26, at 29.

29. See authorities cited in note 23 supra.

30. A study by Dr. Robert Martinson of 231 rehabilitation projects, conducted here and abroad between 1945 and 1967 , concluded that "[w]ith few and isolated exceptions, the rehabilitative efforts that have been reported so far have no appreciable effect on recidivism." J. WiLson, supra note 5, at 169; see Bennet, Rehabilitation in Check, TRIAL, March 1976, at 12; Carlson, supra note 26, at 32; Flynn, Turning Judges Into Robots?, TRIAL, Marclı 1976, at 18.

31. "Despite the weight of authority supporting the principle of dangerousness, it must be rejected because it presupposes a capacity to predict quite beyond our present or foreseeable technical ability." Morris, The Future of Imprisonment: Toward a Primitive Philosophy, 72 MicH. L. REv. 1161,1167 (1974). See also A. voN HiRsch 21; Dersliowitz, supra note 24, at 98. 
parole boards in fact tend to overpredict dangerousness, ${ }^{32}$ thus unjustifiably confining many non-dangerous individuals. ${ }^{33}$ Many criticize indeterminate sentencing for its failure to provide rules and standards to guide sentencing and correctional officials in their exercise of discretion. ${ }^{34}$ Neither judges nor parole boards are required to articulate reasons for their decisions; those decisions are, in any event, rarely reviewed by appellate courts. ${ }^{35}$ This exercise of unchecked discretion has often resulted in disparity in punishments imposed upon similarly situated offenders, ${ }^{36}$ as well as in punishments disproportionate to the seriousness of particular offenses. ${ }^{37}$ Moreover, offenders often perceive additional injustice in indeterminate sentencing because they see uncertainty about the actual period of confinement as a painful and unnecessary aspect of prison hife. ${ }^{38}$

\section{B. The Emergence of Determinate Sentencing.}

As the "rehabilitative ideal" 39 began to fall from favor, determinate sentencing proposals that were behieved to promote justice and to deter crime gained popularity. By fixing sentences proportionate to the seriousness of particular offenses, legislators could eliminate disparities in punishments between similarly situated offenders and give each offender his "just deserts." 40 Fixed sentences, with limitations on probation and parole, would also increase the certainty of the degree of punishment upon conviction, thereby promoting deterrence. ${ }^{41}$ Like retributivists, many deterrence theorists advocating determinate sentencing required proportionahity between the degree of punishment inflicted and the severity of the offense..$^{42}$

32. M. Frankel, supta note 1 , at 100.

33. See Morris, supra note 31 , at $1168-69$.

34. See TASK ForCe Report 13; A. von Hirsch 28.

35. TASK FORCE REPORT 13.

36. "Grotesque disparities are revealed in the sentences inposed for the same classes of offenders in one state as compared to another state, by different courts within the same jurisdiction, and even by individual judges meting out punishment to different offenders." Id. 4-5. See also A. VON HIRSCH 12, 29.

37. See note 17 supra.

38. AMERICAN FRIENDS SERv. COMM., supra note 4, at 93. One of the major factors contributing to inmates' discontent at the time of the 1971 Attica uprising was the uncertainty concerning release dates, which resulted from sentence indeterminacy. N.Y. SPECIAL COMM'N ON ATTICA, AtTICA 91-102 (1972). See also A. von Hirsch 29, 31.

39. The "rehabilitative ideal" characterizes the use of sentencing dispositions to reduce crime by isolating and rehabilitating offenders.

40. See generally A. von Hirsch.

41. See E. VAN DEN HAAG, supra note 2, at 133-36; J. WILSON, supra note 5, at 162-82.

42. See, e.g., van den Haag, supra note 5, at 149-50, 195. The proportionality principle is also expressed in classical deterrence theories: "Venture more against a great offense than a sunall 
Proposed determinate sentencing schemes have taken two forms: presumptive sentencing and mandatory sentencing. Under presumptive sentencing, statutes classify crimes according to seriousness and assign to each category a fixed, presuinptively proper, sentence. That sentence must be imposed upon each convicted offender, except that the sentencing authority is allowed-within specified limits or percentages - to reduce or enhance the presumptive sentence if aggravating or mitigating circumstances are present. ${ }^{43}$ Discretionary release through parole or suspension of sentence is abolished, and the offender serves the entire term, subject perhaps to "good time" reductions necessary to mamtain prison discipline. ${ }^{44}$

Unlike presunptive systems, pure mandatory model $s^{45}$ permit no deviation from the fixed penalty even if "aggravating or mitigating" circumstances exist. As with presuinptive sentencing, the offender is required to serve the full sentence without the possibihty of discretionary parole release, suspension of the sentence, or probation, but with some deviations froin the fixed sentences for "good time" permitted. ${ }^{46}$ Variants of mandatory sentencing require the offender to serve a minimum statutory term without the possibility of lesser pumishinent or discretionary release, but permit judicial discretion to impose, up to a statutory maximum, a sentence exceeding the prescribed minimum term. ${ }^{47}$

Legislatures in several states have recently enacted presumptive sentencing systems. ${ }^{48}$ Although systematic use of mandatory sentenc$\mathrm{mg}$ is nowhere reflected im current practice, ${ }^{49}$ such schemes are being considered. ${ }^{50}$ Moreover, many state criminal codes require mandatory sentencing for particular crimes (most often drug and weapons offenses) and for habitual criminality. ${ }^{51}$

one. ... The greater the mischief of the offense, the greater is the expense, which it may be worthwhile to be at, in the way of punishment." Bentham, The Utilitarian Theory of Punishment, in Punishment 25, 29 (J. Feinberg \& H. Gross eds. 1975).

43. See TASK Force Report 40-48; A. von HirSch 99-101.

44. See A. von Hirsch \& K. HANRAhan 41-45. To insure that sentences are indeed fixed, and that inmates at all times know the actual length of their sentences, advocates of determmate sentencing urge that "good time" systems, if adopted at all, be carefully detailed through specific guidelines defining how inuch good time may be gamed or lost and for what behavior. Id.

45. For a discussion of mandatory or "flat time" sentencing, see TASK FORCE REPORT 16-17.

46. Id.

47. $I d$.

48. See note 7 supra.

49. See note 7 supra.

50. In his 1975 Message to Congress on Crime, then President Ford perhaps tacitly approved inandatory sentencing in suggesting that "it may be time to give serious study to the concept of socalled 'flat-time sentencing' in the Federal Law." Quoted in TASK FORCE REPORT I6.

51. See note 7 supra. 


\section{The Problems of Excessive Punishment.}

Because of its emphasis on proportioning punishment to the gravity of the offense, ${ }^{52}$ determinate sentencing encounters two problems that must be solved if punishment is to be justly and coherently administered: proportioning punishment to victim harm, ${ }^{53}$ and proportioning punishment to offender fault. ${ }^{54}$ The problem of proportioning pumishment to victim harm already exists in soine penal systems. For example, several states mandate life imprisoninent for a person convicted of his third felony regardless of the nature of the felonies. ${ }^{55}$ In those states offenders can commit three minor, non-violent, property offenses and receive the same punishment they would have received had they committed rape or murder. ${ }^{56}$ A state arguably encounters similar problems of punishment disproportionate to victim harm when it imposes punishment far more severe than other states impose for the same offense. ${ }^{57}$ Fixing punishment for a particular offense or for habitual criminal status $^{58}$ without regard to the special circumstances of individual cases also risks the possibility of punishment disproportionate to offender fault. 59 Although this possibility is particularly likely under mandatory sentencing systeins, it also arises under presumptive sentencing systems that too narrowly constrict the instances im which individual circumstances may be considered, ${ }^{60}$ or that define the mitigating factors too

52. See van den Haag, supra note 5, at 191-95.

53. This Article does not address the problems of criminal pumishment as they relate to socalled "victimless crimes."

54. Bedau, supra note 14 , at 67 . The problems are less serious with indeterminate sentencing systems. First, because mdeterminate sentencing is based on rehabilitating and incapacitating offenders, relating severity of punishment to the seriousness of offenses is unnecessary. Second, to the extent that proportionality is desirable in indeterminate systems, it tends to be a natural byproduct of the discretion granted to sentencing authorities who are thoroughly famihiar with the facts of the case. See notes 17-19 supra and accompanying text.

55. See, e.g., Tex. Penal Code AnN. tit. 3, § 12.42(d) (Vernon 1974).

56. This is, of course, precisely what happened in Rummel v. Estelle, 445 U.S. 263 (1980). See the discussion in the text accompanying notes 160-63 infra.

57. See, e.g., In re Foss, 10 Cal. 3d 910, 519 P.2d 1073, 112 Cal. Rptr. 649 (1974), in which the offender successfully attacked a ten-year mandatory sentence imposed on second offenders because, inter alia, the sentence was excessive when compared with sentences imposed in other jurisdictions for second narcotics convictions.

58. Punishment for a "status" offense is constitutionally permissible. Spencer v. Texas, 385 U.S. 554 (1967); Oyler v. Boles, 368 U.S. 448 (1962).

59. Sentences proportioned to offender fault require allowance for individualization of sentences, "for [such sentences] condemn not only the wrong done, the offending act, but also the wrongdoer, the offender." Golding, Criminal Sentencing: Some Philosophical Considerations, in Justice AND Punishment, supra note 14, at 102.

60. The need for precision in defining what constitutes aggravating and mitigating circumstances is illustrated by the following example:

In a single term five defendants appear before the court charged with kidnapping. No. 1

is a woman whose baby died, and who took another woman's baby from the hospital 
narrowly ${ }^{61}$ or the aggravating factors too broadly. ${ }^{62}$

\section{Pre-Rummel Eighth Amendment Cases}

Increasingly, the courts have viewed the punishment problems discussed above as matters within the scope of the cruel-and-unusual-punishments clause of the eighth ainendinent. As discussed below, ${ }^{63}$ several state and Iower federal courts, relying on Supreme Court cases construmg the eighth amendinent, had found legislatively set punishments unconstitutionally excessive because they were disproportionate to victim harm and offender fault. But just when the increasing use of determinate sentencing now makes this form of judicial review most desirable, the Supreine Court in Rummel v. Estelle ${ }^{64}$ has sharply undercut reliance on the eighth ainendinent as a means of constraming excessive punishment in non-capital cases. Because the case law precedimg Rummel was effective im limiting excessive punishment, and because Rummel itself departed so abruptly from that case law, a review of the cases preceding Rummel will be instructive.

\section{A. Supreme Court Cases.}

The Supreme Court traditionally viewed the eighth amendment's proscription of cruel and unusual punishments as prohibiting only the imposition of certam kinds rather than degrees of punishment. Thus, in the nineteenth-century cases of Wilkerson $v$. Utah ${ }^{65}$ and In re

\footnotetext{
No. 2 is a young man whose girlfriend said she was breaking up with him. He put her in a car and drove her around for 24 hours trying to persuade her to change her mind, while her frantic parents tried to locate them and the girl did everything she could to get away. No. 3 is a divorced man who took his own child from its mother who had legal custody and refused to tell the mother where the child was. No. 4 is a kidnapper for ransom who kept a young woman buried in a box fitted with air tubes for breathing in order to make it impossible for searchers to find her, and who demanded $\$ 200,000$ from her wealthy father. No. 5 is a woman accomplice of the kidnapper for ransom. She assisted in the kidnapping because she was in love with the kidnapper and was also threatened by him. She did everything she could to keep the kidnapped girl alive when it was impossible for her to do so.

The offenses charged are identical: kidnapping. How should they be disposed of? Golding, supro note 59, at 93-94.

61. Failure to take into consideration all matters touching on culpabihity may result in unjustly harsh sentences. See id. See also notes 11-12 supra and accompanying text.

62. Characteristics such as the defendant's race, appearance, and sex are clearly inappropriate as aggravating conditions of offender fault. Others such as the offender's failure to plead guilty, cooperate with authorities, or be contrite are more troublesome. See TASK ForCE REPORT 42-44. In any event, sentences in excess of the presumptive term that are premised on inappropriate aggravating conditions are disproportionate to offender fault.

63. See text accompanying notes $118-55$ infra.

64. 445 U.S. 263 (1980).

65. 99 U.S. 130 (1878).
} 
Kemmler, ${ }^{66}$ the Court confined its analysis to the constitutionahity of the particular modes of pumishment imposed in those cases-execution by shooting and execution by electricity. Although the Court recognized the difficulty of precisely defining the reach of the cruel-and-unusual-punishments clause, it affirmed that the eighth amendment forbids punishments of torture or punishments that bring about a lingering death. ${ }^{67}$

1. Non-Capital Punishment Cases. In 1910, however, in Weems v. United States, ${ }^{68}$ the Court first suggested that punishments could be unconstitutional because of their duration alone. The punishment at issuc-cadena temporal ${ }^{69}$ - was imposed in the Philippines for the falsification of public documents. Cadena temporal mcluded a minimum sentence of twelve years and one day, in chains, at "hard and pamful labor"; the loss of many civil rights; and lifetime surveillance. ${ }^{70}$ While acknowledging the possibility that the punishment included "the cruelty of pain"71 and that the eighth amendment prohibits "inhuman and barbarous" modes of punishment, ${ }^{72}$ the Court broadened its prior eighth amendment analysis by finding that an otherwise acceptable sentence can be so disproportionate to the offense for which it is imposed as to constitute cruel and unusual punishment. ${ }^{73}$ In applying this proportionality principle to the punishment of cadena temporal, the Court first compared the punishment with that prescribed for the same offense in the United States and found the Philippime punishment to be much more severe. ${ }^{74} \mathrm{Next}$, the Court conipared the challenged punishment with the punishment prescribed in the Philippines for forging or counterfeiting obligations or securities and found that the maximum punishment for that more serious offense was no greater than that im-

66. 136 U.S. 436 (1889).

67. Id. at 447; Wilkerson v. Utah, 99 U.S. at 135.

68. 217 U.S. 349 (1910).

69. Cadena temporal is Spanish for "temporary cham."

70. 217 U.S. at 364-65. The petitioner, a United States government officer, was convicted of falsifying two items on a public document and was sentenced to fifteen years imprisonment plus the additional penalties. Id. at 362-63. The Court chose not to review the punishment as applied, but rather focused its analysis on "the minimum degree of the law, for it is with the law that we are most concerned." Id. at 366.

71. Id. at 366.

72. Id. at 368. In reference to the Court's similar language in In re Kemmler, 136 U.S. 436, 447 (1890), the Weems Court stated, "It was not meant in the language we have quoted to give a comprehensive definition of cruel and unusual punishment, but only to explain the application of the provision to the punishment of death." 217 U.S. at 370-71.

73. 217 U.S. at 367.

74. Id. at 380 . 
posed for the falsification of a single itern of a public document. ${ }^{75}$ The Court found these anounalies to be more than inere exercises of legislative judgment. Rather, they were evidence that the pumshment was cruel and unusual. ${ }^{76}$ Cadena temporal was found, in short, to be unconstitutional "both on account of [its] degree and kind."77 Weems thus established a two-part analysis of punishments: a comparison of the punishment at issue first with the punishment imposed for the same offense in other jurisdictions, and second with that imposed for other offenses in the same jurisdiction. ${ }^{78}$

The Weems Court's use of proportionality analysis, and the language of the opinion itself, suggested that a sentence could, solely because of its length, be so disproportionate to a particular crime as to constitute cruel and unusual punishment. ${ }^{79}$ Lower courts later interpreted Weems in this manner in holding certain prison sentences unconstitutionally excessive. ${ }^{80}$

The Supreme Court did not allude to the proportionality doctrine again until the 1958 decision of Trop $v$. Dulles, ${ }^{81}$ which held that denationalization is an unconstitutional punishment for the crime of wartime desertion. Proportionality was not the basis for the holding, however: "Since wartime desertion [can be punished] by death, there

75. Id. at $380-81$.

76. In other words, the highest punishment possible for a crime which may cause the loss of many thousand[s] of dollars, and to prevent which the duty of the State should be as eager as to prevent the perversion of truth in a public document, is not greater than that which may be imposed for falsifying a single iten of a public account. . . . [T]his contrast . . . condemns the sentence in this case as cruel and unusual.

Id. at 381 .

77. Id. at 377 (emphasis added).

78. The Weems Court also considered the nature of the offense itself to be relevant to the cruelty of the punishment, noting twice that one could be convicted of document falsification even without realizing any gain or injuring anyone. Id. at 363,365 . This facet of the analysis has not, however, been emphasized in cases following Weems.

79. After Weems the Conrt in Graham v. West Virginia, 224 U.S. 616 (1912), upheld a mandatory life sentence imposed under West Virginia's recidivist statute, noting: "Nor can it be Inaintained that cruel and unusual punishment has been infiicted." Id. at 63I. At the time of this decision, however, the eighth amendment had not been held applicable to the states through the fourteenth amendment. Furtherinore, the Graham Court considcred the defendant to be challenging the validity of the recidivist legislation and the proceedings that it authorized rather than the proportionality of the sentence imposed. See id. at 623.

Four years later in Badders v. United States, 240 U.S. 391 (1916), the Court upheld concurrent sentences of five years' inprisonment and cumulative fines of $\$ 1,000$ on each of seven counts of placing letters in the inail for the purpose of executing a single scheme to defraud, stating only: "[T]here is no ground for declaring the punishment unconstitutional." Id. at 394. Badders, like Graham, was heard long before the eighth amendment was applied to the states in Robinson v. California, 370 U.S. 660 (1962).

80. See note 121 infra and accompanying text. See also People v. Lorentzen, 387 Mich. 167, 171-79, 194 N.W.2d 827, 829-33 (1972).

81. 356 U.S. 86 (1958). 
can be no argument that the penalty of denationalization is excessive in relation to the gravity of the crime." 82 The Court articulated a policy basis for eighth amendment analysis: "The basic concept underlying the Eighth Amendment is nothing less than the dignity of inan. While the State has the power to punish, the Amendment stands to assure that this power be exercised within the limits of civilized standards." 83 Although the Court did not dispose of Trop on disproportionahity grounds, it did use the interjurisdictional analysis applied in Weems in finding that only two of eighty-four nations of the world imposed denationalization as a punishinent for desertion. ${ }^{84}$

Four years after Trop, in Robinson v. California ${ }^{85}$ the Supreme Court for the first time directly apphed the eighth amendment's crueland-unusual-punishinents clause to a state-imposed punishment. The Court lield unconstitutional a California statute that made the status of narcotics addiction a criminal offense pumshable by incarceration for ninety days in the county jail. ${ }^{86}$ "To be sure," said the Court, "imprisonment for ninety days is not, im the abstract, a punishment which is either cruel or unusual. But the question cannot be considered in the abstract. Even one day in prison would be cruel and unusual punishment for the 'crime' of having a common cold." 87 The eighth amendment underpinnings of the Robinson holding are uncertam; although it is clear fron the quoted language that the Court was not holding imprisoninent as a mode of pumshment to be cruel and unusual, ${ }^{88}$ it is not clear that the Court was relying on the disproportionality doctrine to strike down the statute. ${ }^{89}$ Because Robinson is a problematic eighth ainendment case, its relevance to the proportionality doctrine is questionable. 90

82. Id. at 99.

83. Id. at 100 .

84. Id. at 103 .

85. 370 U.S. 660 (1962).

86. Id. at 667 .

87. $I d$.

88. The defense had argued that imprisonment of the drug addict would be cruel and unusual because it would impose "intense mental and physical torment and suffering; via the "coldturkey' withdrawal method." Brief for Appellant at 30, Robinson v. California, 370 U.S. 660 (1962).

89. The Court did not even cite the Weems opinion, but rather cited Francis v. Resweber, 329 U.S. 459 (1947), which held that executing a defendant by electrocution after an earher attempt at electrocution had failed because of mechanical difficulty was not cruel and unusual. Robinson v. California, 370 U.S. at 666 . Because Francis focused on the mode of punishment and not its proportionality to the crime, 329 U.S. at 464, the Robinson Court's holding was presumably not based on the proportionality doctrine.

90. Mr. Justice White's dissenting opmion suggested that the true ground of Robinson was a resurrected forin of substantive due process: 
2. Capital Punishment Cases. After Robinson, in a series of death penalty cases, ${ }^{91}$ the Court took the opportunity to develop more fully the disproportionality analysis originated in Weems. In Furman $v$. Georgia $^{92}$ the Court held that the eighth anendment prohibited the infliction of capital punishment under virtually all the state statutes then in force..$^{93}$ All nine Justices wrote separate opinions, with a majority citing Weems for the proposition that the eighth amendment prohibits excessive as well as inherently cruel punishments. ${ }^{94}$

Similarly, in Gregg v. Georgia, ${ }^{95}$ which held the punishment of death not to be per se unconstitutional for the crime of murder, ${ }^{96}$ a three-justice plurahity of the Court found the excessiveness as well as the barbarity of punishment to be crucial to eighth alnendment inquiry. In articulating the considerations relevant to review under the amendment, the plurahty noted that society's attitude towards a challenged sanction-determined by objective criteria such as the history and traditional use of the punishment, ${ }^{97}$ current legislative trends regarding its use, ${ }^{98}$ and its frequency of imposition by juries ${ }^{99}$-is a significant indicator of the punishment's cruelty. ${ }^{100}$ Public perceptions regarding a punishment are not conclusive, ${ }^{101}$ lowever, for the penalty must also accord with "the dignity of inan"-the basic concept underlying the

1 deem this application of "cruel and unusual punishment" so novel that I suspect the Court was hard put to find a way to ascribe to the Framers of the Constitution the result reached today rather than to its own notions of ordered liberty. If this case involved economic regulation, the present Court's allergy to substantive due process would surely save the statute and prevent the court from imposing its own philosophical predilections upon state legislatures or Congress.

370 U.S. at 689 (White, J., dissenting). See also 29 BrookLyn L. Rev. 139, 141 (1962).

91. Coker v. Georgia, 433 U.S. 584 (1977); Roberts v. Louisiana, 428 U.S. 325 (1976); Woodson v. North Carolina, 428 U.S. 280 (1976); Jurek v. Texas, 428 U.S. 262 (1976); Proffit v. Florida, 428 U.S. 242 (1976); Gregg v. Georgia, 428 U.S. 153 (1976); Furman v. Georgia, 408 U.S. 238 (1972).

92. 408 U.S. 238 (1972).

93. Justices Douglas, Stewart, and White found it unconstitutional under the eighth amend. ment to leave the imposition of the death penalty to the untrainmeled discretion of judges or juries. Id. at 256 (Douglas, J., concurring); id. at 310 (Stewart, J., concurring); id. at 314 (White, J., concurring). Justices Brennan and Marshall held that the inposition of the death penalty is constitutionally impermissible per se. Id. at 305 (Brennan, J., concurring); id. at 370 (Marshall, J., concurring).

94. See 408 U.S. at 266, 280 (Brennan, J., concurring); id. at 325 (Marshall, J., concurring); id. at $456-57$ (Powell, J., dissenting, joined by Burger, C.J., Blackmun, J., and Rehnquist, J.).

95. 428 U.S. 153 (1976).

96. Id. at 169.

97. Id. at 176-79.

98. Id. at $179-81$.

99. Id. at $181-82$.

100. Id. at 173 .

101. Id. 
eighth amendment. 102 "This means, at least, that the punishment may not be 'excessive'. . . . First, the punishment must not involve the unnecessary and wanton imfliction of pain. Second, the punishment must not be grossly out of proportion to the severity of the crime."103

In Woodson v. North Carolina ${ }^{104}$ the Court held unconstitutional a statute that mandated the death penalty for persons convicted of inurder. ${ }^{105}$ A plurality of the Court, $\mathrm{m}$ applying the objective indicators set forth in Gregg, assessed as follows the conteinporary sentimient regarding mandatory death penalties: "The behef no longer prevails that every offense im a like legal category calls for an identical punishment without regard to the past hife and habits of a particular offender. [T] he death sentence [is no longer] an autoniatic and commonplace result of convictions . . . "106 Regarding Gregg's "dignity of man" concept, the plurality stated:

While the prevailing practice of individualizing sentencing determinations generally reflects simply enlightened policy rather than a constitutional imperative, we believe that in capital cases the fundainental respect for humanity underlying the Eighth Amendment, . . . requires consideration of the character and record of the individual offender and the circumstances of the particular offense as a constitutionally indispensable part of the process of inflicting the penalty of death. ${ }^{107}$

102. Id.

103. Id. "Although we cannot "invalidate a category of penalties because we deein less severe penalties adequate to serve the ends of penology, . . . the sanction imposed cannot be so totally without penological justification that it results in the gratuitous infliction of punishment." Id. at 182-83 (citation oinitted). The plurality identifled retribution and deterrence as the penological purposes underlying the death penalty. Id. at 183. In the past the Justices had differed sliarply over the role of retribution in capital cases. Compare Furman v. Georgia, 408 U.S. 238, 344-45 (1972) (Marsluall, J., concurring) ("To preserve the integrity of the Eighth Amendment, the Court has consistently denigrated retribution as a permissible goal of punishment. . . [T] he Eighth Amendment is our insulation froin our baser selves") with id. at 394 (Burger, C.J., dissenting) ("There is no authority suggesting that the Eighth Amendinent was intended to purge the law of its retributive elements, and the Court has consistently assumed that retribution is a legitimate dimension of the punishment of crimes") and id. at 453 (Powell, J., dissenting) ("While retribution alone may seem an unworthy justification in a unoral sense, its utihty in a system of criminal justice requiring public support has long been recognized"). See also Williains v. New York, 337 U.S. 241, 248 (1949) ("Retribution is no longer the dominant objective of the criminal law. Reformation and relabilitation of offenders have become important goals of criminal jurisprudence").

104. 428 U.S. 280 (1976).

105. Id. at 305. See also Roberts v. Louisiana, 428 U.S. 325 (1976) (holding unconstitutional the mandatory death penalty for five narrowly defined categories of first-degree murder).

106. 428 U.S. at 296-97 (quoting Williams v. New York, 337 U.S. 241, 247 (1949), which held that the due process clause did not prevent the sentencing judge froun considering information froin out-of-court sources in determining the kind and extent of punishment to impose).

107. 428 U.S. at 304 (citations ounitted). The Court cited Pennsylvania ex rel. Sullivan v. Ashe, 302 U.S. 51, 55 (1937), for the proposition that "[f]or the determination of sentences, justice generally requires consideration of more than the particular acts by whicl the crime was commit- 
The Court emphasized the distinction between capital and non-capital offenses by stating that its conclusion rested "squarely on the predicate that the penalty of death is qualitatively different from a sentence of imprisonment, however long." 108

Although the Court held the death penalty not to be disproportionate to the crime of inurder in Gregg, ${ }^{109}$ a four-justice plurahity in Coker v. Georgia"10 cited Weems as support for the view that "the Eightl Amendment bars not only those pumshments that are 'barbaric' but also those that are 'excessive' in relation to the crime committed," 111 and lield the capital sanction to be "grossly disproportionate and excessive punishment for the crime of rape."112 In so holding, the Coker plurality assessed the seriousness of rape as compared to murder. "Rape is without doubt deserving of serious punishment, but in terms of moral depravity and of the injury to the person and to the public, it does not compare with murder, which does involve the unjustified taking of human life." 113

The effects of these Supreme Court death penalty cases on the proportionality doctrine developed in Weems is not clear. Furman, Gregg, and Woodson seem to require, at the very least, that before the death penalty can be constitutionally imposed, the sentencing authority must consider the cliaracter and record of the individual offender and the circumstances of the particular offense. 114 Moreover, the "excessiveness" test spelled out in Gregg and Coker seems to focus on victim harn, requiring that an imposed pumshment be proportionate to the severity of the crime. ${ }^{115}$ Whether these sentencing criteria are constitutionally mandated in non-capital cases was not made clear, because in each of the capital cases the Court eniphasized the uniqueness of the death penalty for purposes of eighth amendment analysis. ${ }^{116}$ Nevertheless, the analytical tools developed in the capital cases appear equally

ted and that there be taken into account the circumstances of the offense together with the character and propensities of the offender." 428 U.S. at 304.

108. 428 U.S. at 305.

109. 428 U.S. at 169.

110. 433 U.S. 584 (1977).

111. Id. at 592 .

112. Id.

113. Id. at 598.

114. Woodson v. North Carolina, 428 U.S. at 303-04.

115. Coker v. Georgia, 433 U.S. at 592; Gregg v. Georgia, 428 U.S. at 173.

116. Coker v. Georgia, 433 U.S. at 598 (the death penalty is unique in its severity and irrevocability); Woodson v. North Carolina, 428 U.S. at 305 (the death penalty is "qualitatively different from a sentence of imprisonment, however long"); Gregg v. Georgia, 428 U.S. at 187 ("'t]here is no question that death is unique in its severity and irrevocability"); Furman v. Georgia, 408 U.S. at 306 (Stewart, J., concurring) (the death penalty "differs from all other forms of crimmal punishment"). 
useful for non-capital cases; indeed, Weems's two-pronged analysis ${ }^{17}$ itself provides a sufficiently objective standard by which to assess the proportionality of a non-capital sentence to the seriousness of its underlying offense.

\section{B. State and Lower Federal Court Cases.}

Even before the Supreine Court death penalty cases, lower courts, relying on Weems, were deciding excessive punishment cases by assessing the proportionality of prison sentences not only as they related to offenses in the abstract, but also as applied to the circumstances of particular offenders. The California Supreme Court in In re Lynch, ${ }^{118}$ for example, addressed the question whether an indeterminate sentence for a second conviction for indecent exposure-a conviction potentially amounting to life imprisonment because no maximum term is imposed ${ }^{119}$-constitutes cruel or unusual punishment under Califorma's constitution. ${ }^{120}$ Drawing lieavily from Weems, the court articulated three distinct standards for determining whether a punishment "is so disproportionate to the crime for which it is inflicted that it shocks the conscience and offends fundamental notions of human dignity." 121 The first standard called for an examination of the seriousness of the offense and the culpability of the offender. ${ }^{122}$ The circumstances of the crime in question, the degree of violence inherent in the offense, and any rational gradations of culpability that can be made on the basis of injury to the victim were all considered relevant to the evaluation of seriousness. ${ }^{123}$ The second and third standards essentially followed the

117. See text accompanying notes 74-78 supra. Weems is also cited for the principle that a punishment is excessive if it fails to serve a penological purpose. See Furman v. Georgia, 408 U.S. at 280 (Brennan, J., concurring); Gregg v. Georgia, 428 U.S. at 173.

118. 8 Cal. 3d 410, 503 P.2d 921, 105 Cal. Rptr. 217 (1972).

119. Id. at 419,503 P.2d at 927,105 Cal. Rptr. at 223.

120. CAL. Const. art. I, §6. California prohibits "cruel or unusual punishment," a logically different formulation from the federal prohibition on cruel and unusual punishment. This difference, however, was not significant to the Lynch court.

121. $8 \mathrm{Cal}$. 3d at 424, 503 P.2d at $930,105 \mathrm{Cal}$. Rptr. at 226. The court noted that the proportionality doctrine had been adopted at the federal level in Weems: "Although undoubtedly influenced by the peculiar penalties imposed in addition to imprisonment, the court did not hold the law unconstitutional merely on the ground of the bizarre method of punishment." Id. at 421, 503 P.2d at 928, 105 Cal. Rptr. at 224.

122. Id. at 425,503 P.2d at 930,105 Cal. Rptr. at 226.

123. Id. at 425-26, 503 P.2d at 930-31, 105 Cal. Rptr. at 226-27. The Lynch court noted that the Weems Court had einphasized the minor nature of the offeuse before it: "[T] he opinion twice notes that the amonnt of cash which the defendant was convicted of falsely claiming as a governinent expenditure was only a few hundred pesos, and twice underscores that an offender may 'gain nothing' from this crime and 'injure nobody'." Id. at 425, 503 P.2d at 931, 105 Cal. Rptr. at 227 (citations omitted). 
two prongs of the Weems proportionality test: a comparison of the challenged punishment with punishments imposed withm the same jurisdiction for other offenses ${ }^{124}$ and a comparison of the challenged punishment with punishments prescribed in other jurisdictions for the same offense. ${ }^{125}$

In applying this three-part analysis to the defendant's potential life sentence, the Lynch court found that the nonviolent nature of the offense, ${ }^{126}$ the lesser penalties prescribed im California for more serious crimes, ${ }^{127}$ the lack of enhanced punishments for repetition of most other crimes, ${ }^{128}$ the short jail sentences and fines imposed by other states for initial and subsequent indecent exposure offenses, ${ }^{129}$ and the failure of the punishment to fit the defendant and the circumstances of his offense ${ }^{130}$ rendered the sentence unconstitutionally disproportionate to the offender's fault and the offense's harn. ${ }^{131}$

Two years after Lynch the California Supreme Court in In re Foss ${ }^{132}$ applied the Lynch formula to strike down a statutory provision $^{133}$ imposing a mandatory minimum sentence of ten years upon an offender convicted of a second drug-related felony. The defendant Foss, a heroin addict suffermg from withdrawal, on five separate occasions acquired heroin for Holmes, a fellow drug addict who claimed he was going through withdrawal. Foss, who had never sold drugs for profit, received as consideration a single fix of herom on three of the five occasions. ${ }^{134}$ Foss was convicted on five counts of selling or furnishing heroin; because he had been convicted fourteen years before of possession of heroin, he was sentenced to a mandatory minimum term of ten years witl a maximum of hife. ${ }^{135}$ Foss challenged the statute under the California constitution's cruel-or-unusual-punishment clause. ${ }^{136}$

In applying the Lynch standards, the Foss court looked not only to the nature of the offense and the offender, but also to the penological

124. Id. at 426,503 P.2d at 931,105 Cal. Rptr. at 227.

125. Id. at 427, 503 P.2d at 932, 105 Cal. Rptr. at 228.

126. Id. at 430,503 P.2d at 934,105 Cal. Rptr. at 230.

127. Id. at 431,503 P.2d at 935,105 Cal. Rptr. at 231.

128. Id. at 434, 503 P.2d at 937, 105 Cal. Rptr. at 233.

129. Id. at 436, 503 P.2d at 938-39, 105 Cal. Rptr. at 234-35.

130. Id. at 437,503 P.2d at 939,105 Cal. Rptr. at 235.

131. Id. at 439, 503 P.2d at 940, 105 Cal. Rptr. at 236. For an analysis of $L y n c h$ see 6 Loy.

L.A. L. REv. 416 (1973).

132. 10 Cal. 3d 910, 519 P.2d 1073, 112 Cal. Rptr. 649 (1974).

133. Cal. Health \& Safety Code \& 11352 (West Supp. 1980).

134. 10 Cal. 3d at 918,519 P.2d at 1077,112 Cal. Rptr. at 653 .

135. Id. at 915-16, 519 P.2d at 1075-76, 112 Cal. Rptr. at 651-52.

136. Id. at 917-18, 519 P.2d at 1077, 112 Cal. Rptr. at 653. 
purposes of the punishment in light of the particular offense. ${ }^{137}$ The court first noted that enhanced sentences for repeated narcotics offenses should be based on the particular circumstances of the offenses, such as the quantity of narcotics involved and whether the transactions were those of an addict supporting his habit or were instead sales for profit. 138 The court concluded that the mandatory minimum sentence as applied to the defendant was disproportionate to his degree of fault because the statute failed to allow for the offender's particular circumstances. ${ }^{139}$ Moreover, because rehabilitation of the offender was the statute's primary goal, 140 the court found that the statute's preclusion of parole consideration for ten years was clearly excessive, because Foss might well have been rehabilitated before ten years. ${ }^{141}$ The second and third of the Lynch standards ${ }^{142}$ alse required a finding of unconstitutionality under the state constitution: the mandatory sentence was unusually severe as compared both to recidivist sentences imposed in California for more serious offenses ${ }^{143}$ and to minimum terms imposed in other states for second narcotics convictions. ${ }^{144}$

Although Lynch and Foss were decided on state constitutional grounds, their clear Weems pedigree suggests that those state courts would have reached the same results had they directly apphed the eighth amendment. Lynch and Foss thus show that proportioning punishment to offender fault as well as to victim harm not only is judicially pessible, but also might be found constitutionally necessary under the eighth amendment. Mandatory sentences are especially suspect because they prevent the consideration of particular circumstances necessary to a just imposition of punishment. California cases subsequent to Foss have limited its holding to sentences imposed on recidivists. ${ }^{145}$

The Foss court has not been alone in finding certain mandatory

137. Id. at 923,519 P.2d at 1081,112 Cal. Rptr. at 657 .

138. Id. at 921,519 P.2d at 1080, 112 Cal. Rptr. at 655 .

139. Id. at 923, 519 P.2d at 1081, 112 Cal. Rptr. at 657 .

140. Id.

141. Id. at 924,519 P.2d at 1081, 112 Cal. Rptr. at 657.

142. See text accompanying notes 124-25 supra.

143. 10 Cal. $3 d$ at 925,519 P.2d at 1082, 112 Cal. Rptr. at 658 .

144. Id. at 928,519 P.2d at 1084, 112 Cal. Rptr. at 660 . Justice Clark dissented on the ground that the sentencing judge could have exercised his inherent power to strike the prior conviction had mitigating circumstances led him to believe that the interests of justice would have been furthered by not subjecting the defendant to the recidivist provisions of the statute. Id. at 933-34, 519 P.2d at 1088, 112 Cal. Rptr. at 664 (Clark, J., concurring and dissenting). Justice Clark's opinion suggests that sentencing discretion was necessary to the constitutionality of the recidivist statute.

For a discussion of the Foss case, see 20 N.Y.L.F. 655 (1975); 63 CAL. L. REv. 289 (1975).

145. The California Supreme Court in In re Grant, 18 Cal. 3d 1, 13, 553 P.2d 590, 598, 132 Cal. Rptr. 430, 438 (1976) noted: 
prison sentences to be cruel and unusual. ${ }^{146}$ The Court of Appeals for the Fourth Circuit in Hart $v$. Coiner, ${ }^{147}$ applying an eighth ainendinent analysis very similar to that used in Lynch and Foss under California's

Provisions which preclude parole consideration for specified periods become disproportionate to the offense when they not only indiscriminately penalize repeated conduct of widely varying gravity without regard for regularly recurring mitigating factors, but also absolutely preclude parole for substantial lengths of time in excess of that reasonably calculated to allow for consideration of reliabilitative progress or to fulfill otler legitimate penological objectives.

(emphasis added). The Grant court specifically reserved opinion as to mandatory minimum-term provisions for first offenders. Id. at $13 \mathrm{n} .10,553 \mathrm{P} .2 \mathrm{~d}$ at $598 \mathrm{n} .10,132 \mathrm{Cal}$. Rptr. at $438 \mathrm{n} .10$. The California appellate courts have upleeld inandatory minimuin term provisions for first offenders. See People v. Waters, 52 Cal. App. 3d 323, 125 Cal. Rptr. 46 (1975) (upholding a tlree-year mandatory mimimum term for conviction of conspiracy to sell and the sale of a controlled substance); People v. Carbonie, 48 Cal. App. 3d 679, 121 Cal. Rptr. 831 (1975) (upholding a five-year mandatory minimum term for using a minor as an agent to furnish a controlled substance); People v. Serna, 44 Cal. App. 3d 717, 118 Cal. Rptr. 904 (1975) (uplıolding a three-year mandatory minimum term for the sale of heroin). But cf. People v. Vargas, 53 Cal. App. 3d 516, 126 Cal. Rptr. 88 (1975) (holding a three-year inandatory term for furmishing a controlled substance unconstitutional as applied to a defendant who had a ininimum criminal record, was not a major offender or dangerous cliaracter, was not a drug user, and had furnished only a small amount of a nonaddictive substance from which no harm actually resulted).

146. For example, the Kentucky Court of Appeals in Workman v. Commonwealth, 429 S.W.2d 374 (Ky. 1968), held unconstitutional a inandatory life sentence for the crime of rape as applied to a fourteen-year-old. The court applied three tests in judging the sentence's constitutionakity: whether in view of all the circuinstances the punishinent sloocked the conscience, whether the punishment was disproportionate to the offense, and whether the punishment exceeded what was necessary to achieve any legitimate aim. Id. at 378 . The court found that the intent of the legislature in imposing the punishment was to deal with dangerous and incorrigible offenders who would be a constant threat to society, and that it was impossible to predict that a fourteen-year-old would remain incorrigible for the rest of his life. Id.

In People v. Lorentzen, 387 Micl. 167, 194 N.W.2d 827 (1972), the Michigan Supreine Court held unconstitutional a nuandatory minimum sentence of twenty years for the offense of selling marijuana. In determining the proportionality between the punishment and the offense, the court first applied the two-pronged comparative test set forth in Weems. The court then looked to the penological considerations underlying indeterminate sentencing, finding that relrabilitation, the primary goal, was best achieved by short, indeterminate sentences. The court concluded that "[a] compulsory prison sentence of 20 years for a non-violent crime imposed without consideration for defendant's individual personality and history is so excessive that it 'shocks the conscience.' "Id. at 181, 194 N.W.2d at 834. See also State v. Evans, 73 Idaho 50, 245 P.2d 788 (1952), in which the court avoided holding unconstitutional a statute that apparently inandated life imprisonment for the crime of committing lewd and lascivious acts upon a female child by construing the statute to permit the sentencing judge to fix a maximum sentence that could be less than life.

Other state courts, accepting the validity of the Weems proportionality doctrine, have applied objective standards such as those used in Foss and have found the cliallenged inandatory sentence not to be disproportionate to the crime cominitted. See State v. Freennan, 223 Kan. 362, 574 P.2d 950 (1978) (upholding a mandatory minimum sentence of five years for committing inurder with a firearni); Cominonwealth v. Jackson, 344 N.E.2d 166 (Mass. 1976) (uplılding a inandatory minimum sentence of one year for a first conviction of carrying a firearn without a license); People $v$. Broadie, 37 N.Y.2d 100, 332 N.E.2d 338, 371 N.Y.S.2d 471 (uplolding a inandatory life sentence for the sale of heroin or cocaine), cert. denied, 423 U.S. 950 (1975); State v. Lee, 87 Wash. 2d 932, 558 P.2d 236 (1977) (upholding a mandatory life sentence imposed under a habitual crimmal statute upon commission of the third felony).

147. 483 F.2d 136 (4th Cir. 1973), cert. denied, 415 U.S. 983 (1974). 
constitution, held unconstitutional a mandatory life sentence imposed, under West Virginia's habitual criminal statute, ${ }^{148}$ on an offender convicted of perjury, writing a $\$ 150$ check on insufficient funds, and transporting across state lines forged checks totalling $\$ 140$. The Hart court relied upon four criteria to determine the disproportionahity of the sentence: (1) the nature and gravity of the offense; (2) the legislative purpose behind the punishment; (3) a comparison of how the defendant would have been punished in other jurisdictions; and (4) a comparison of punishinents iniposed in the same jurisdiction for more serious crimes. ${ }^{149}$ In assessing the nature and gravity of the offense, the court looked to the specific facts surrounding the defendant's underlying offenses, noting that they were nonviolent, that the bad check offense was nearly a inisdemeanor, ${ }^{150}$ and that the perjury conviction, though more serious than the other offenses, was initigated somewhat because the defendant had been forced to choose between family loyalty and his duty to be trutliful. ${ }^{151}$ As to the legislative purpose of the punishment-deterring others and protecting society-the court found that life imprisonment (the most severe punishment possible under West Virginia law) was not necessary to protect society or to deter others from committing the crimes the defendant had committed. ${ }^{152}$ The comparative analyses under the third and fourth criteria also showed the iniposed punishment to be unconstitutionally severe. ${ }^{153}$ The Hart court concluded that the mandatory life sentence was im this case "wholly disproportionate to the nature of the offenses he committed, and not necessary to achieve any legitimate legislative purpose."I54

148. W. VA. CODE \& 61-11-18 (1966). The defendant did not attack the statute itself but contended that the mandatory life sentence was disproportionate as apphed to the underlying offense. 483 F.2d at 139.

149. 483 F.2d at $140-42$.

150. "[O]ne penny less in the face amount of the check and the offense would have been a fiveto-sixty day petty inisdeineanor." Id. at 141.

151. Id. at $140-41$.

152. Id. at 141. In its analysis of legislative purpose, the court relied upon Justice Brennan's observation in Furman that a punishment is unnecessary and excessive if a significantly less severe punishment would achieve the saine purpose. Id. Justice Brennan's view was later rejected in Gregg v. Georgia, 428 U.S. at 182-83.

153. $483 \mathrm{~F} .2 \mathrm{~d}$ at $141-42$.

154. Id. at 143. The Hart decision should be compared with Griffin v. Warden, 519 F.2d 756, 757 (4th Cir. 1975), which upleeld a mandatory life sentence inposed upon a defendant convicted of grand larceny, burglary, and breaking and entering, all within a six-year period, because the crimes were "serious offenses that clearly involve the potentiality of violence and danger to life as well as to property."

In Davis v. Davis, 601 F.2d 153 (4th Cir. 1979) (en banc), vacated and remanded sub nom. Hutto v. Davis, 100 S. Ct. 1593 (1980) (remanded for further consideration in light of Rummel v. Estelle, 445 U.S. 263 (1980)), the Court of Appeals for the Fourth Circuit held unconstitutional a sentence of forty years' inprisonment and a $\$ 20,000$ fine for possession and distribution of less 
The willingness of lower courts to examine prison sentences under the analysis emerging from Weems and Lynch has not resulted in frequent findings of excessive punishment. Indeed, cases like Lynch, Foss, and Hart are extremely rare even though the courts are constantly petitioned to overturn allegedly excessive sentences. ${ }^{155}$ The lower appellate courts have cautiously apphed proportionality analysis to prison sentences, routmely deferring to legislative and sentencing-court decisions regarding the appropriate degrees of punishment for given offenses and offenders. That sentences are rarely overturned as excessive, however, in no way lessens the necessity of judicial review as a check on unduly harsh pumshments. Furthermore, because Weems, Foss, and Hart all involved determinate sentences, they prominently demonstrate the usefulness of a judicial safety valve as the movement toward determinate sentencing gathers steain.

\section{RUMMEL V. ESTELLE}

Although Robinson v. California ${ }^{156}$ touched off the review of several state-imposed prison sentences, ${ }^{157}$ the Supreme Court did not comment further on the appropriateness of the aniendnient as a measure of proportionality of punishment in non-capital cases. ${ }^{158}$ The Court recently broke its silence, however, in Rummel $v$. Estelle, ${ }^{159}$ a case that dramatically highlights the problenis of proportioning punishment to offender fault and victim harm under systems of niandatory sentencing.

\section{A. The Holding and Rationale of Ruminel.}

In Rummel a five-to-four inajority of the Court upheld a inandatory life sentence imposed on the petitioner, whose three felonies over a nine year period-for fraudulently presenting a credit card with intent to obtain approximately $\$ 80$, passing a forged instrument in the ainount of $\$ 28.36$, and obtaining $\$ 120.75$ by false pretenses-triggered

than nine ounces of marijuana. The Davis holding makes it apparent that Hart was not limited to cases involving life sentences.

155. See note 146 supra and the cases cited and discussed in Annot., 33 A.L.R.3d 335 (1970). Indeed, Justice Rehnquist himself in Rummel noted this rarity, 445 U.S. at 272, as if that were a reason for finding a particular punishment not to be excessive.

156. 370 U.S. 660 (1962). Robinson established the applicability of the eighth amendment's cruel-and-unusual-punishment clause to the states. See text accompanying notes 85-90 supra.

157. See, e.g., Perkins v. North Carohna, 234 F. Supp. 333 (W.D.N.C. 1964); Faulkner v. State, 445 P.2d 815 (Alaska 1968); State v. Espinosa, 101 Ariz. 474, 421 P.2d 322 (1966); State v. Nance, 20 Utah 2d 372, 438 P.2d 542 (1968).

158. "[S]ince Weems was decided in 1910, there has been no opimion in the Supreme Court which has struck down a noncapital punishment on proportionality grounds." Mulligan, Cruel and Unusual Punishments: The Proportionality Rule, 47 FordHAM L. REv. 639, 644 (1979).

159. 445 U.S. 263 (1980). 
the application of Texas's habitual criminal statute. ${ }^{160}$ By downplaying the apphicability of the proportionality doctrine for assessing lengths of sentences, ${ }^{161}$ and giving the utmost respect to the principle of federalism, ${ }^{162}$ the majority opinion by Mr. Justice Rehnquist found that petitioner Rummel's sentence did not constitute cruel and unusual punishment. ${ }^{163}$

The Rummel Court did not wholly reject the eighth amendment proportionality doctrine, ${ }^{164}$ but did severely restrict its applicability to cases challenging the length of sentences. First, the Court declined to follow the analysis formulated in the death penalty cases, by finding those cases to be of "limited assistance" because of the unique nature of the penalty involved. ${ }^{165}$ Second, the Court refused to interpret Weems as holding that in a non-capital case a prison sentence could, solely because of its length, be so disproportionate to the underlying crime as to constitute cruel and unusual pumishment. ${ }^{166}$ Rather, the Court found the Weems holding to be based upon facts peculiar to that case: "the triviality of the charged offense, the impressive length of the minimum term of imprisonment, and the extraordinary nature of the 'accessories," which included chains, hard labor, and the loss of basic civil rights. ${ }^{167}$ The Court completed its narrowing of Weems by noting that "one could argue without fear of contradiction by any decision of this Court that for crimes concededly classified and classifiable as felonies ... the length of the sentence actually imposed is purely a matter of

160. Tex. Penal Code art. 63 (1925): "Whoever shall have been three times convicted of a felony less than capital shall on such third conviction be imprisoned for life in the penitentiary." The 1974 Penal Code preserved art. 63, with minor variation. See TEX. PENAL CoDE ÁNN. tit. 3, § 12.42(d) (Vernon 1974).

161. 445 U.S. at $272-76$.

162. Id. at $282-84$.

163. Id. at 285 .

164. "This Court has on occasion stated that the Eighth Amendment prohibits imposition of a sentence that is grossly disproportionate to the severity of the crime." Id. at 271.

165. Id. at 272 .

166. Id. at $272-73$.

167. Id. at 274. This reading of Weems appears to be inconsistent with the Court's prior understanding of the case as stated in Gregg v. Georgia, 428 U.S. at 171:

Although the [ $\mathrm{Weems}$ ] Court acknowledged the possibility that "the cruelty of pain" may be present in the challenged punishment, it did not rely on that factor, for it rejected the proposition that the Eighth Amendinent reaches only punishments that are "inhuman and barbarous, torture and the like." Rather, the Court focused on the lack of proportion between the crine and the offense....

(citations ounitted). Dissenting in Rummel, Justice Powell noted: "In both capital and noncapital cases this Court has recognized that the decision in Weems v. United States "proscribes punislment grossly disproportionate to the severity of the crime.' " 445 U.S. at 290 (Powell, J., dissenting) (citations omitted). 
legislative prerogative."168

Expressing its reluctance to review legislatively determined sentences, the Rummel Court reiterated that "Eighth Amendinent judginents should not be, or appear to be, inerely the subjective views of individual Justices; judgment should be informed by objective factors to the maximum possible extent." 169 The Court found that no objective criteria could be invoked to measure the proportionahity of Rummel's life sentence to the crimes he committed. The Court also chose not to minimize the seriousness of his offenses, despite their lack of violence, because "the presence or absence of violence does not always affect the strength of society's interest in deterring a particular crime or in punishing a particular criminal." 170 As to the sinall anounts of inoney involved in Rummel's crimes (a total of $\$ 229.11$ ), the Court refused to hold that these amounts were outside any threshold sum that would warrant life imprisonment, noting instead that the subjective judgment of where to draw the line was properly within the province of the state legislature. ${ }^{171}$ Furthermore, the Court observed that it did not have to decide whether Rummel's life sentence was proportionate to his offenses because Rummel was not being pumshed for those offenses specifically, but rather for his status as a three-time offender. ${ }^{172}$

168. 445 U.S. at 274. To support this proposition the Court cited Badders v. United States, 240 U.S. 391 (1916), which upheld concurrent sentences of five years' imprisonment and cumulative fines of $\$ 1,000$ on each of seven counts of mail fraud; and Graham v. West Virginia, 224 U.S. 616 (1912), which upheld a life sentence imposed upon an "incorrigible horse thief." 445 U.S. at 276. The dissent, however, noted that both of these holdings are of doubtful relevance to Rummel: in Badders, the Court merely explains that a five-year sentence for the commission of seven crimes is not cruel and unusual and the Court's one-sentence holding im Graham predates the application of the eighth ainendinent to the states. Id. at 290-91 n.7 (Powell, J., dissentimg).

169. 445 U.S. at 274-75 (citing Coker v. Georgia, 433 U.S. at 592). In Coker the statement cited here follows immediately after the "excessiveness" test set forth in that opinion. See 433 U.S. at 592.

170. 445 U.S. at 275 . The court cited an exainple:

Caesar's death at the hands of Brutus and his fellow conspirators was undoubtedly violent; the death of Hamlet's father at the hands of his brother, Claudius, by poison, was not. Yet there are few, if any, States which do not pumish just as severely inurder by poison (or attempted murder by poison) as they do murder or attempted murder by stabbing.

Id. at 282-83 n.27. Certainly poisoning is a more violent act than, for example, embezzlement. Accordingly, inurder by poisonimg is objectively a more serious offense than embezzlement. Moreover, in Coker the Court did not hesitate to distinguish the gravity of murder and rape on the basis of "moral depravity" and "injury to the person and to the public." See note 113 supra and accompanying text. As noted by the Rummel dissent, distinguishing the seriousness of crimes on the basis of the violence involved is surely no more difficult or subjective than distinguishing them on the basis of "moral depravity." Id. at 295-96 n.12 (Powell, J., dissenting).

171. Id. at $275-76$.

172. Id. Justice Powell refused to accept this approach, stating that the nature of the offenses was relevant to an objective proportionahity analysis. Id. at 301 (Powell, J., dissenting). 
The Court next compared Texas's recidivist statute ${ }^{173}$ with those of other states. ${ }^{174}$ That only two other states-West Virginia and Washington - could have punished Rummel as severely as Texas did ${ }^{175}$ suggested merely that Texas was not alone in its view of proper punishments. ${ }^{176}$ Moreover, because recidivist statutes exist in a variety of forms, the Court thought it difficult to draw interjurisdictional coinparisons. The Court noted that a number of states would require life imprisonment upon conviction of four rather than three felonies, that others would impose life sentences if one or more of three felomies were violent, and that still others would permit discretionary life sentences after three felony convictions. 177 State-to-state variations in "good time" credits, differing parole possibilities, and the existence of prosecutorial discretion often exercised in screening out petty offenders, further illustrated the complexities involved in comparing recidivist schemes. ${ }^{178}$ Finally, the Court found that even if the Texas statute were the inost stringent in the fifty states, that factor alone would not inake Rummel's punishment "grossly disproportionate" to his crimes: the primciples of federalisin permit one state to treat a particular type of offender more severely than other states would. ${ }^{179}$

Unpersuaded of the relevance of comparing the Texas statute to similar statutes in other jurisdictions, the court also played down the fact that Rummel's crimes were punished as severely as, or more se-

173. See note 160 supra. Under Texas law a three-time felon receives a mandatory life sentence only if he has served time in prison after each of two successive convictions for felomes and is then convicted of a third felony. 445 U.S. at 278.

174. In making these comparisons, the Court agreed with Rummel that his inabihity to enforce any "right to parole" precluded the Court from treating his life sentence as if it were a 12-year sentence even though Rummel would theoretically be ehigible for parole after serving that period. Id. at 280. Paradoxically, however, the Court believed that 'a proper assessment of Texas' treatment of Rummel could hardly ignore the possibility" of parole. Id. (emphasis added).

175. See WAsh. Rev. Code ANN. § 9.92.090 (West 1977); W. VA. Code § 61-11-18 (1977). The majority opimion ignored the fact that nine other states had once enacted statutes as severe as Texas's but had subsequently repealed them., 445 U.S. at 296 \& n.13 (Powell, J., dissenting).

176. See 445 U.S. at 279.

177. Id. at 279-80. The dissent rehed upon these very same considerations as evidencing the disproportionality of Rummel's life sentence:

More than three-quarters of American jurisdictions have never adopted an habitual offender statute that would commit the petitioner to mandatory life imprisonment. The jurisdictions that currently employ habitual offender statutes either (i) require the commission of more than three offenses, (ii) require the commission of at least one violent crime, (iii) limit a mandatory penalty to less than life, or (iv) grant discretion to the sentencing authority. In none of the jurisdictions could the petitioner have received a mandatory life sentence merely upon the showing that he committed three nonviolent property-related offenses.

Id. at 298-99 (Powell, J., dissenting).

178. Id. at 281 .

179. rd. 
verely than, Texas might punish murder or rape. ${ }^{180}$ Noting that different crimes offend different societal interests, thus rendering intrajurisdictional comparisons of crimes and punishments "inherently speculative," 181 the Court concluded that "a State cannot be required to treat persons who have committed three 'minor' offenses less severely than persons who have committed one or two 'more serious' offenses." 182 The Court based this conclusion on its perception of recidivist statutes as a vahd means of deterring and segregating incorrigible offenders. ${ }^{183}$ There is "little in the way of objective standards," the Court concluded, "for judging whether or not a life sentence imposed under a recidivist statute for several separate felony convictions not involving 'violence' violates . . . the Eighth Amendinent."184 The amount of time a recidivist offender nay be incarcerated is thus entirely a matter of legislative discretion. ${ }^{185}$

\section{B. A Critique of Rummel.}

Although Rummel clearly marks a new era of himited application of the eighth amendment as a protection against excessive punishment, the extent of the limitation is not certain. The Court may have curtailed the application of the proportionality doctrine only in the context of recidivist statutes. Indeed, much of the difficulty the Court encountered in relating proportionality analysis to Ruminel's case occurred because Rummel's punishment was premised nore on his status as a repeat offender than on the nature of his individual crimes. The Court viewed the proportionality doctrine, with its einphasis on making the punishment fit the seriousness of a particular offense, as largely inapplicable to recidivist statutes. Such a narrow reading of Rummel would leave courts free to apply the eiglith amendment to declare unconstitutional the excessive pumshment of a single offense.

States could, of course, effectively bypass this eighth amendment review of single offense punishments simply by casting the relevant statute as one directed to recidivisin: if conviction for the offense in question represented the offender's second (or higher) conviction of any

180. See id. at 300-01 (Powell, J., dissenting); $c f$. id. at 282-83 n.27 (unajority opinion). Firsttime capital murderers in Texas were subject to mandatory life sentences or death. TEX. PENAL CODE ANN. tit. 3, $\$ 12.31$ (Vernon 1974). Aggravated rapists were subject to sentences from five to ninety-nime years. Id. $\$ 12.32$ (Vernon Supp. 1979). A person twice convicted of simple rape could have received a five-year sentence. 445 U.S. at 301 (Powell, J., dissenting).

181. 445 U.S. at 282 n.27.

182. Id.

183. See id. at 276.

184. Id. at 283 n.27.

185. Id. at 285. 
kind, a harsh sentence could be imposed. Any minor misdemeanor could thus become the predicate for hife imprisonment for a secondtime offender.

This constitutional dodge would not be necessary, however, if Rummel is read more broadly; indeed, although Rummel addresses a recidivist statute, there is little reason to limit its holding to such statutes. If the nonviolence and pettiness of Rummel's crimes provided no objective grounds to invalidate his recidivist punishment, it is difficult to see how or why such considerations could ever support striking down legislatively imposed penalties for single offenses. Moreover, niany of the complexities that rendered useless an interjurisdictional comparison of recidivist statutes by the Rummel Court ${ }^{186}$ - such as state-to-state variations in defining a given offense, administering good time and parole, and exercising prosecutorial discretion in screening out petty offenders-would also render useless similar comparisons of the various treatments of single offenses.

Whether broadly or narrowly read, however, the majority opinion in Rummel offers several targets for criticism. One particularly imviting target is the Court's outright rejection of the death penalty cases as guidance for the constitutional analysis of prison sentences. Although the Court had previously emphasized the uniqueness of the death penalty for purposes of eighth amendment analysis, ${ }^{187}$ "[n]othing in the Coker analysis suggests that principles of disproportionality are applicable only to capital cases." 188 As noted above, ${ }^{189}$ the Coker analysis is easily applied in non-capital cases as well. Furthermore, if "qualitative difference" and "uniqueness" are the keys that open a capital case to this forn of analysis, ${ }^{190}$ then a distimction should also be made between hife imprisonment and imprisonment for a fixed term, and between any term of imprisonment and a fine. This is especially true since the eighth aniendment refers to "punishment," and not merely to "execution."

Another target for criticism in the Rummel decision is its departure from the eighth amendment interpretation of cases like Lynch and Hart. ${ }^{191}$ The Rummel Court asserted that Weems should be limited to

186. See notes 177-78 supra and accompanying text.

187. See note 116 supra and accompanying text.

188. 445 U.S. at 292-93 (Powell, J., dissenting). The Coker analysis was that "a punishment is excessive and unconstitutional if it: (1) makes no measurable contribution to acceptable goals of punishment and hence is nothing more than the purposeless and needless imposition of paim and suffering; or (2) is grossly out of proportion to the severity of the crime." 433 U.S. at 592.

189. See text accompanying notes 115-17 supra.

190. See note 116 supra.

191. See text accompanying notes 118-31, 147-54 supra. 
its facts; 192 accordingly, Weems cannot provide guidance for assessing any punishment but cadena temporal. Yet previous Supreme Court decisions in Furman v. Georgia ${ }^{193}$ and Coker v. Georgia ${ }^{194}$ have applied the Weems rationale to the death penalty. To suggest that Weems justifiably extends beyond its facts to the death penalty cases because the capital sanction is inore severe than cadena temporal leaves Weems's inapplicabiliy in Rummel unexplained: Rummel's life sentence is arguably a more severe punishment than cadena temporal.

An assessnient of severity can, of course, be subjective, and the Rummel Court makes clear that subjectivity is to be avoided. ${ }^{195}$ Yet the Court's repeated emphasis on the subjectivity of judgments regarding the seriousness of various criminal offenses is singularly mappropriate in the context of eighth amendment review. Such skepticism overlooks the judicial duty to apply a constitutional text forbidding cruelty, an inherently value-laden concept inevitably requiring assessments of moral matters. To be sure, one cannot easily determine whether a given crime is serious or trivial, or whether one crime is inore or less serious than another, ${ }^{196}$ but it does not follow that such determinations are always impossible to make or even that they are mevitably subjective matters. ${ }^{197}$ After all, the Rummel Court itself concededpresuinably on the basis of subjective considerations, because it articulatcd no objective ones-that a life sentence might well be unconstitutionally excessive pumshment for the crime of overtime parking. ${ }^{198}$ Indeed, it is a matter of moral common sense that even "a month in prison for overparking is too severe." 199 If the Court's moral intuitions could reliably guide it to an assessment of punishments for overtime parking, similar intuitions could have rehiably led to an assessment of Ruminel's sentence.

192. See 445 U.S. 263,274 (1980).

193. 408 U.S. 238 (1972). See text accompanying notes 92-94 supra.

194. 433 U.S. 584 (1977). See text accompanying notes 109-13 supra.

195. 445 U.S. at 274-76 (1980).

196. Some crimes, such as sex and drug offenses, are particularly controversial. The perceived seriousness of these offenses often hinges on local standards of decency and particular problems created by the incidence of the offenses within a given jurisdiction. Note, Disproportionality in Sentences of Imprisonment, 79 CoLuM. L. REv. 11 19, 1142 (1979).

197. Einpirical studies of popular perceptions of the relative seriousness of offenses show substantial agreement among different racial, occupational, and educational subgroups. "[P]eople from widely different walks of life can inake common-sense judgments on the comparative gravity of offenses and come to fairly similar conclusions." A. vON HIRsCH 79. Rehnquist himself made such a judgment when he observed that attempted fraud is "no less blameworthy" than actual fraud. Rummel v. Estelle, 445 U.S. at 276.

198. 445 U.S. at 274 n.11.

199. Bedau, supra note 14, at 65 . 
The Court's rejection of both inter- and intrajurisdictional comparisons is equally troubling for inuch the same reason. As H.L.A. Hart has observed:

The guiding principle is that of a proportion within a system of penalties between those imposed for different offences where these have a distinct place in a commonsense scale of gravity. This scale itself no doubt consists of very broad judgments both of relative moral iniquity and hannfulness of different types of offense .... Yet maintenance of proportion of this kind may be important: for where the legal gradation of crimes expressed in the relative severity of penalties diverges sharply from tlis rough scale, there is a risk of either confusing coinmon morality or flouting it and bringing the law into conteinpt. ${ }^{200}$

The "commonsense scale of gravity" indicates that an offender committing one murder or rape deserves greater pumshment than an offender committing three petty, nonviolent property offenses. ${ }^{201}$ But even if one viewed the gravity of a single instance of rape or murder as less than that of repeated, though less violent, criminal conduct, commonsense justice would certainly preclude inflicting Rummel with the same punishment that would be imposed on another recidivist offender whose three felonies included a rape or a murder. ${ }^{202}$

Yet after Rummel no eighth amendment principle precludes a state from punishing any offense with any non-capital sentence, as long as the punishment arguably promotes some penological purpose. If Texas is permitted to pumish Rummel as it has, why cannot highly urbanized State $X$ punish overparking, a matter of serious concern in the state because of inadequate parking space and imsufficient mass transportation, with hife inıprisonment if the legislature sees a strong need to deter overparking? Moreover, in the Rummel Court's view it would be constitutionally irrelevant that every other state imposed less severe punishments for overparking, and that State $X$, because its low incidence of violent crimie required hittle deterrence, punished rape and murder less severely than overparking.

200. H.L.A. HART, Prolegomenon to the Principles of Punishment, in PUNISHMENT AND RESPONSIBILITY 1, 25 (1968).

201. The judicial practice of assessing proportionality by comparing the challenged sentences with those authorized by other states for similar offenses arose in the course of reviewing sentences for inurder, rape, and forgery, traditional crimes about which the opinion on relative gravity varies hittle from state to state. In the rare instances in which the relative severity of punishments authorized for traditional crimes conflicts with the widely lield opinion of the offense's gravity, courts should feel confident in overturning the sentence as disproportionate.

Note, supra note 196, at 1142 (footnotes oinitted).

202. See id. 1165. In Texas, three non-capital murders or three rapes would be punished under the same statute applied to Rummel. See note 160 supra for the statutory language. 
Furthermore, the rejection of Rummel's life sentence based on common-sense justice or under the Weems's proportionality analysis would not have offended the principle of federalism. Although federalism acknowledges the power of states to experiment with a variety of methods for dealing with deviancy, ${ }^{203}$ that power is subject to the substantive limits of the eighth amendment's guarantee against cruel and unusual punishment. ${ }^{204}$ Mr. Justice Brennan's criticism of the Court's recent performance $\mathrm{m}$ protecting individual rights is telling:

Adopting the premise that state courts can be trusted to safeguard individual rights, the Supreme Court has gone on to limit the protective role of the federal judiciary. But in so doing, it has forgotten that one of the strengths of our federal system is that it provides a double source of protection for the rights of our citizens. Federalism is not served when the federal half of that protection is crippled. ${ }^{205}$

Fears that federal intervention into state legislative decisions under a subjective standard would be excessive can easily be allayed by a requirement that courts adhere to objective standards such as Weems's interjurisdictional and intrajurisdictional comparisons. Even under the gentlest scrutiny, the fact that Rummel would have been punished far less severely had he committed his offenses in any of forty-seven otler states supports the common-sense conclusion that the Texas punishment was too severe.

The Court's failure to apply common-sense judgments and objective primciples of proportionahity to Rummel's case resulted in the affirmation of a punishment disproportionate to both the fault of the offender and the harn to his victims. This outcome portends damage to the integrity of the crimmal justice system itself because it "risks confusing and flouting common norality and bringing the law into contempt."206

203. The doctrine of federalism is often viewed as a means of encouraging state-to-state experimentation with a variety of different punishment schemes. See, e.g., Coker v. Georgia, 433 U.S. at 618-19 (Burger, C.J., dissenting).

204. See Note, supra note 196, at 1134.

205. Brennan, State Constitutions and the Protection of Individual Rights, 90 HARv. L. Rev. 489, 502-03 (1977) (footnotes omitted). The need for federal review of state punishments is especially necessary in light of the apparent irrationality sometimes manifested in administering the criminal sanction. For example, in a single jurisdiction one offender committing robbery by assault received an eight-year sentence while another offender committing the same crimc received a fifty-year sentence. See Goudeau v. State, 478 S.W.2d 456 (Tex. Criin. 1972); Grayson v. State, 468 S.W.2d 420 (Tex. Crim. App. 1971). Moreover, for the seemingly less serious offense of possession of inarijuana, one offender was sentenced to 100 years of imprisonment. Albro v. State, 502 S.W.2d 715 (Tex. Crim. 1973). Texas appellate courts upheld all of these sentences against constitutional attack on grounds of cruel and unusual punishment.

206. H.L.A. HART, supra note 200, at 25. 


\section{Alternative Checks on Excessive Punishment}

Although the Rummel Court paid lip service to the proportionality doctrine, 207 it effectively abandoned it. Hence, the Court has virtually precluded the future use of the eighth amendment as a check on excessive punishment except in capital cases. Rummel's failure to require that punishment be tied to the nature of the offense, and its rejection of inter- and intrajurisdictional comparison, effectively drained the strength from each of the objective criteria used in Weems and in lower court decisions to assess the excessiveness of punishments. ${ }^{208}$ The fears of one commentator appear to have been borne out by Rummel: The eighth ainendinent has become "moribund"; "cruel and unusual punishment" is simply a "shibboleth" in the context of excessive incarceration. ${ }^{209}$

We are left, then, with a situation of increasing use of determinate sentencing, with its attendant risks of punishment disproportionate to offender fault and victim liarm, and witlout eighth amendment checks on such punishment. Because no new procedure in the criminal justice system is likely to replace judicial review, various other means of limiting excessive punishment must now assume greater prominence than before. Effective use of these mechanisms can partially compensate for Rummel's emasculation of prior case law.

\section{A. Drafting Considerations.}

Injustice in sentencing can be largely avoided if legislatures exercise wisdown in drafting determinate sentencing schemes. Three considerations are particularly crucial: a general attitude of parsimony in administering incarceration, a choice of presumptive rather than mandatory sentencing systems, and care in defining the aggravating and mitigating circumstances called for under presumptive systems.

1. Parsimony in Use of Imprisonment. The risk of excessively long imprisonment can be reduced if prison terms are imposed only when less restrictive sanctions wonld fail to achieve defined social pur-

207. See note 164 supra.

208. Rummel does not specifically mention the "least drastic means" analysis applied in the lower court cases. Its status as an eighth amendment standard is strongly called into question, however, by the Rummel Court's uncritical acceptance of the penological objectives of isolation and deterrence as sufficient justification for Rummel's sentence. Clearly, the Court is unconcerned about whether those penological objectives could be effectively realized through alternatives less drastic than a sentence of life imprisonment.

209. See Mulligan, supra note 158, at 649. 
poses. $^{210}$ If less restrictive sanctions would be inappropriate, the duration of incarceration for a given crime should be the minimum period that the typical first offender committing the crime in the typical fashion deserves, and that is necessary to protect the state's interest in deterring the crime. 211 Longer incarceration for subsequent convictions can be provided, ${ }^{212}$ but again only to the extent necessary to satisfy considerations of desert and deterrence. ${ }^{213}$ A limitation such as three or five years should be set, before which the courts will not look to find offenses to be counted under a recidivist statute. Furthermore, punishment for recidivism should be expressly proportioned to the underlying offenses.

Clearly this balancing of desert and utility will not always yield satisfactory results. While the typical offender inay deserve $x$ years imprisonment for a given crime, considerations of deterrence may be thought to require $x+1$ years. Such situations should be relatively uncommon, however, if (as it seems) deterrence is promoted more effectively througl certainty than througl severity of punishment. ${ }^{214}$ Even a compromise between desert and deterrence is unlikely to constitute disproportionate punisliment if the primciple of parsimony is observed. Moreover, the requirement that punishment be set for the typical first-time offender-not for the occasional egregious wrongdoer-helps to ensure that punishment will be proportionate to the gravity of the offense and to the culpability of most offenders, not only in an absolute sense but also in relation to offenders committing other offenses.

2. Presumptive Rather Than Mandatory Sentencing. Although defining pumshment in terms of typical offenders committing crimes in typical fashions will roughly proportion the punishment to victim harm and offender fault, a presuinptive sentencing system allows an even closer proportioning. Attention to such criteria as the offender's motive

210. See N. MoRris, supra note 5, at 60-62. See also Model Penal Code $\$ 7.01$ (Proposed Official Draft 1962) for an embodiment of the principle of parsimony in administering punishment; TASK FORCE REPORT 32 ("We urge that, im general, presumptive sentencing be accompanied by a considerable reduction in the lengths of sentences authorized by legislatures, inposed by courts, and served by prisoners"); A. vON HIRSCH \& K. HANRAHAN 104 (standards governing durations of imprisonment must be parsimonious).

211. See TASK ForCe RePORT 20.

212. See id.

213. Abandoning concerns for rehabilitating and isolating offenders in favor of considerations of desert and deterrence is necessary if punishments proportionate to crimes are to be set legislatively. Such an approach is, of course, consistent with the theoretical underpinnings of the determinate sentencing movement. See notes 30-42 supra and accompanying text.

214. See, e.g., J. WILSON, supra note 5, at 174. 
for committing the crime, his powers of self-control, the strength of the teinptations facing him, and his social and cultural upbringing is required if punishment is to correspond accurately to offender fault.215 Victim harm also may vary from case to case, depending on the manner in which the crime was committed. Presumptive sentencing takes these variable elements into account to provide a check on excessive incarceration; inandatory punishment scheines lack this check.

The flexibility of presuinptive systeins need not remtroduce the very drawbacks of indeterminate systems that the determinate sentencing novement seeks to avoid. ${ }^{216}$ Deviations from the presumptive norm can be controlled through the careful, prudent defining of aggravating and mitigating circumstances.

3. Care in Defining Aggravating and Mitigating Conditions. Criminal justice theorists have suggested two basic approaches to defining the aggravatimg and mitigatimg conditions that justify deviations from presumptive sentences. One approach is to state broad primciples of aggravation and mitigation; 217 the other is to list specific aggravating and mitigating circumstances. ${ }^{218}$ Although either approacli could assist in proportioning punishment to offender fault and victim harm, a specific listing is preferable, because its precise focus on relevant circumstances diverts attention from those circuinstances that are inappropriate for consideration. ${ }^{219}$

215. See note 11 supra.

216. See text accompanying notes 29-38 supra.

217. See, e.g., A. voN HiRSCH 100.

218. Continental European systems commonly list specific aggravating and initigating factors. See Mueller \& LePoole, Appellate Review of Legal but Excessive Sentenccs: A Comparative Study, 21 VAND. L. REv. 411, 424-29 (1968).

219. A good model list of aggravating and mitigating conditions is provided by a report of the Twentieth Century Fund Task Force, FaIR AND CerTaIN PUNISHMENT. Listed as aggravating factors are:

1. The defendant was the leader of the criminal enterprise.

2. The crime involved several perpetrators.

3. The crime involved several victims.

4. The victim or victims were particularly vulnerable.

5. The victim or victims were treated with particular cruelty during the perpetration of the crime.

6. The degree of physical harm inflicted on the victim or victims was particularly great.

7. The amounts of money or property taken were considerable.

8. The defendant, though able to make restitution, has refused to do so.

9. The defendant had no pressing need for the money taken; he was motivated by thrills or by the desire for luxuries.

10. The defendant has threatened witnesses or has a history of violence against witnesses.

The following constitute mitigating conditions:

1. The defendant played a mimor role in the crime. 


\section{B. Prosecutorial and Jury Discretion.}

Excessive punishment is also less likely if prosecutors bring charges under determinate sentencing schemes against only those offenders believed to merit the full measure of punishment set for the offense. ${ }^{220}$ Such an exercise of discretion is not necessary when prosecutors seek convictions withm indeterminate sentencing systems, because the sentencer can exercise discretion to impose punishment proportionate to the fault of particular offenders. But under mandatory sentencing systems, if decisions about the proportionality of a fixed sentence to the culpability of a particular offender are to be made at all, they must be made by the prosecutor in deciding whether or not to seek conviction. 221

The jury can also provide a check on excessive punishment once a case comes to trial, provided that mitigating circumstances have come to light. In the extrene case, if the jury has evidence of a defendant's good notives or other exculpatory considerations, it can simply exer-

2. The defendant committed the crime under some degree of duress, coercion, threat, or compulsion insufficient to constitute a complete defense but which significantly affected his conduct.

3. The defendant exercised extreme caution in carrying out the crime.

4. The victim or victims provoked the crime to a significant degree by their conduct.

5. The defendant believed he had a claim or a right to the property.

6. The defendant was motivated by a desire to provide necessities for his family or hiunself.

7. The defendant was suffering from a mental or physical condition that significantly reduced his culpability for the offense.

8. The defendant, because of his youth or old age, lacked substantial judgmont im committing the crime.

9. The amounts of money or property taken were dehberately very small and no harm was done or gratuitously threatened against the victim or victims.

10. The defendant, though technically guilty of the crime, committed the offense under such unusual circumstances that it is unlikely that a sustained intent to violate the law motivated his conduct.

TASK FORCE REPORT 44-45. Several of the factors are vague, perhaps purposely so, permitting leeway to accommodate the equities in particular cases. Moreover, the Task Force's report grants common law expansion of the hist if, after a hearing, the sentencing judge decides that an unlisted factor constitutes a legitimate aggravating or mitigating circumstance. Id. 47. If an unlisted factor is used, however, the sentencing judge must write a reasoned opinion, subject to appellate review, stating why the factor is appropriately considered im sentencing. Id. 21. Fimally, the sentencimg authority is permitted to deviate from the presumptive sentences only if the number of aggravating circumstances substantially exceeds the number of mitigatimg circumstances, or vice versa. $1 d$. 46.

For other examples of the "histing" approach, see id. 44-45. See also Fogel, Pursuing Justice in Corrections, in Justice AND Punishment, supra note 14, at 125, 144-46.

220. "The responsibility of a public prosecutor . . . is to seek justice, not merely to convict. . . . [T]he prosecutor . . . should use restraint in the discretionary exercise of governmental powers, such as in the selection of cases to prosecute . . . ABA CODE OF Professional RESPONSIBILITY EC 7-13 (1976).

221. Whether this additional degree of prosecutorial discretion is desirable is a matter beyond the scope of this Article. 
cise its discretion to acquit. 222

\section{Problems with Drafting and Discretionary Approaches.}

Although careful drafting of determinate sentencing statutes might, in theory, ease the problem of excessive incarceration, as a practical matter, such a solution is unlikely to work, for reforms that impose parsimonious punishments for crime are often pohitically unpopular. ${ }^{223}$ Moreover, rehiance on prosecutorial discretion to check excessive punishment will often be misguided, because particular mitigatimg factors may be unknown at the time the offender is charged. Consequently, prosecutors may be unwilling to examine carefully such factors once they are convinced that an accused should be charged, and have initiated proceedings. Fimally, the jury may be unable to exercise its discretion to acquit in light of initigating circumstances of particular cases. For example, unless the defendant's "good inotives" go to one of the recognized substantive defenses such as necessity or self-defense, they may be considered inadmissible and thus may never be brought to the jury's attention. ${ }^{224}$ In addition, when the lack of "mental illness" precludes an insanity defense, mitigating factors such as social, cultural, and economic deprivation, and special inabilities to resist temptation and to exercise self-control, will also be inadmissible.225 Unless the substantive defenses are relaxed to encompass the full range of mitigating factors 226 they will likely remaim outside the jury's consideration. Given these weaknesses in legislative, executive, and administrative checks on excessive punishment, additional safeguards in the form of judicial review of determinate sentences are necessary.

\section{The Need for Judicial Review.}

Although Rummel may have crippled judicial review of sentences of state prisoners, the eighth amendinent can remain an effective vehicle for preventing excessive incarceration in the federal system. Without the concerns of federahsm to restrain them, federal courts may be more inclined to strictly scrutinize federal criminal sentences. The eighth amendment may even retain some vitahity im state cases if $R u m$ -

222. See W. LaFave \& A. Scott, Criminal Law 208 (1972).

223. See Alschuler, supra note 15 , at 569; A. von Hirsch \& K. HanRahan 85-86.

224. W. LAFAVE \& A. SCOTT, supra note 222, at 205-07.

225. H. Fingarette, The Meaning of Criminal Insanity 232 (1972). See also note 11 supra.

226. The author has previously made such a recommendation. Gardner, The Renaissance of Retribution-An Examination of Doing Justice, 1976 WIS. L. REv. 781, 808-11. 
mel is limited to the context of recidivist offender statutes. ${ }^{227}$

A more promising judicial device than the eighth amendment for restraimts on state-miposed pumishments, however, is review under state constitutional prohibitions agaimst cruel and unusual pumishment. ${ }^{228}$ As illustrated by the California Supreme Court decisions in In re Lynch $^{229}$ and In re Foss, ${ }^{230}$ state courts are free under such provisions to carry forth the proportionality analysis developed by the Supreme Court in Weems and in the capital punishment cases. This is true even if Rummel extends beyond recidivist statutes to cover all cases of imprisonment, because states nuay interpret the wording of their own constitutions differently from the imterpretation federal courts give identical wording in the United States Constitution, as long as greater protection of imdividual rights is afforded by the state's imterpretation. ${ }^{231}$ Opinions like Lynch and Foss that grant greater protection than the federal constitution provides under Rummel are therefore immune from review by federal courts. 232 "With federal scrutmy diminished, state courts must respond by mcreasing their own."233

Whether or not other state courts will follow the Cahifornia Supreme Court's lead im requiring punishment to be proportionate to the fault of the offender as a matter of state constitutional doctrine remains to be seen. Certainly, elected state judges may feel the sanie

227. See text accompanying notes 185-86 supra.

228. The prohibitions contained in the Eighth Amendment of the United States Constitution are found in one form or another $\rightarrow$ sonetimes elaborate, most often terse-in the Bill of Rights or Declaration of Rights in all the state constitutions except in Illinois, Vermont, and Connecticut. Ninetecn states proscribe cruel "or" unusual punishment. Twenty-two states prohibit cruel "and" unusual punishment. Six states prohibit only "cruel" punishment, nraking no mention of "unusual." In Illinois the constitution provides that "all penalties shall be proportioned to the nature of the offense"; Vermont has no constitutional provision on the matter, but the state Supreme Court has said that the English Bill of Rights is a part of the common law and as such is applicable; Connecticut has no constitutional provision and no case directly in point, but in a case in which the constitutionality of a statute enhancing the penalty for a second offense was an issue, the highest court in the state quoted with approval the statement: "Nor can it be nuaintained that cruel and unusual punishment has been inflicted."

S. Rubin, Law of Criminal Correction 423 (2d ed. 1973) (footnotes oinitted).

229. 8 Cal. 3d 410, 503 P.2d 921, 105 Cal. Rptr. 217 (1972). See the discussion in text accompanying notes $118-31$ supra.

230. 10 Cal. 3d 910, 519 P.2d 1073, 112 Cal. Rptr. 649 (1974). See the discussion in text accompanying notes $132-44$ supra.

231. State v. Kaluna, 55 Hawaii 361,369 n.6, 520 P.2d 51, 58 n.6 (1974).

232. "[B]y invoking a state constitutional provision, a state court immunizes its decision from review by this Court." Payton v. New York, 445 U.S. 573, 600 (1980).

233. Brennan, supra note 205, at 503. Justice Brennan observed that state courts cannot rest when they have afforded their citizens the full protections of the federal Constitution. ... The legal revolution which has brought federal law to the fore must not be allowed to inhibit the independent protective force of state law-for without it, the full realization of our liberties cannot be guaranteed.

Id. at 491. 
political pressures that restrain legislative action assuring proportionate punishment. Because checks on excessive punishment from legislators, prosecutors, or jurors are unlikely to be effective, however, state courts may afford the only significant protection against excessive punishment in emerging systeuns of determinate sentencing.

\section{CONCLUSION}

The movement to determinate sentencing marks a new era in American criminal jurisprudence. Many of the imjustices of prior indetermmate sentencing inodels are likely to be alleviated, but new problems of proportioning the length of prison terms to offender fault and victim harm are also sure to arise. These problems are particularly significant because a traditional and increasingly effective mode of addressing thein in the past, judicial scrutimy under the eighth amendment, has been einasculated by the Supreme Court's decision in Rummel v. Estelle. With the virtual renoval of the federal courts from the field of state-imposed punishments, responsibility for assuring justice in the administration of sentences rests squarely on the shoulders of state agencies. Failure to meet the new challenges that the movement toward determinate sentencing poses will not only prevent the emergence of a inore just and effective system of administermg the criminal sanction, but inay well result in a system characterized by harshness and a tendency to breed contempt not only among those who feel unfairly treated by the system's inflexibility, but also among those whose duty it is to administer its sanctions. 


\section{.}

